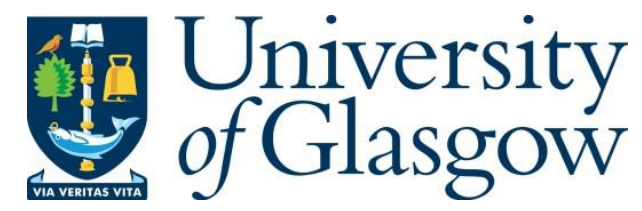

Bao, R., Mcintyre, C., Zhao, M., Zhu, C., Kao, S.-J., and Eglinton, T. I. (2016) Widespread dispersal and aging of organic carbon in shallow marginal seas. Geology, 44(10), pp. 791-794. (doi:10.1130/G37948.1)

This is the author's final accepted version.

There may be differences between this version and the published version. You are advised to consult the publisher's version if you wish to cite from it.

http://eprints.gla.ac.uk/136604/

Deposited on: 16 March 2017

Enlighten - Research publications by members of the University of Glasgow http://eprints.gla.ac.uk 


\section{Widespread dispersal and aging of organic carbon in}

\section{2 shallow marginal seas}

3 Rui Bao ${ }^{1}$, Cameron McIntyre ${ }^{1,2}$, Meixun Zhao ${ }^{3,4}$, Chun $\mathrm{Zhu}^{5}$, Shuh-Ji Kao ${ }^{6}$, and

4 Timothy I. Eglinton ${ }^{1}$

$5 \quad{ }^{1}$ Geological Institute, ETH Zürich, Zurich 8092, Switzerland

$6 \quad{ }^{2}$ Laboratory for Ion Beam Physics, ETH Zürich, Zurich 8093, Switzerland

$7 \quad{ }^{3}$ Key Laboratory of Marine Chemistry Theory and Technology, Ministry of Education,

8 Ocean University of China, Qingdao 266100, China

$9{ }^{4}$ Qingdao Collaborative Innovation Center of Marine Science and Technology,

10 Qingdao 266100, China

$11{ }^{5}$ ExxonMobil Upstream Research Company, 22777 Springwoods Village Parkway,

12 Spring, Texas 77389, USA

$13{ }^{6}$ State Key Laboratory of Marine Environmental Science, Xiamen University, Xiamen

14 361005, China

15 ABSTRACT

16 The occurrence of "pre-aged" organic carbon (OC) in continental margin surface

17 sediments is a commonly observed phenomenon, yet the nature, sources, and causes of

18 this aged OC remain largely undetermined for many continental shelf settings. Here, we

19 present the results of an extensive survey of the abundance and radiocarbon content of

20 OC in surface sediments from the northern Chinese marginal seas. Pre-aged OC is

21 associated with both coarser $(>63 \mu \mathrm{m})$ and finer $(<63 \mu \mathrm{m})$ sedimentary components, with

22 measurements on specific grain size fractions revealing that it is especially prevalent 
23 within the $20-63 \mu \mathrm{m}$ fraction of inner shelf sediments. We suggest that organic matter

24 associated with this "sortable silt" fraction is subject to protracted entrainment in

25 resuspension-deposition loops during which it ages, is modified, and is laterally

26 dispersed, most likely via entrainment within benthic nepheloid layers. This finding

27 highlights the complex dynamics and pre-depositional history of organic matter

28 accumulating in continental shelf sediments, with implications for our understanding of

29 carbon cycling on continental shelves, development of regional carbon budgets, and

30 interpretation of sedimentary records.

\section{INTRODUCTION}

As the major loci of organic carbon (OC) burial in the oceans and the confluence

33 of terrestrial and marine realms, it is crucial to understand the processes that lead to the

34 efflux of $\mathrm{CO}_{2}$ and sequestration of $\mathrm{OC}$ on continental shelves in order to predict potential

35 changes to this important and dynamic component of the carbon cycle. Physicochemical

36 interactions between organic matter $(\mathrm{OM})$ and the mineral matrix are typically invoked as

37 the primary mode of stabilization and sequestration of OM in sediments (Kennedy and

38 Wagner, 2011). Hydrodynamic processes play a critical role in the dispersal and

39 distribution of mineral-associated $\mathrm{OM}$ on continental margins and in the deep sea

40 (McCave and Hall, 2006; Inthorn et al., 2006). Protracted entrainment within

41 resuspension-deposition loops and exposure to oxic conditions may, in turn, influence the

42 properties of OC that accumulates in underlying sediments. Accordingly, the distribution,

43 composition, reactivity, and age of OM preserved in continental margin sediments may

44 be controlled to a significant degree by OM-mineral interactions, with important

45 implications for regional and global carbon budgets (Burdige, 2005; Deng et al., 2006). 
46 However, much remains to be understood concerning the spatial and temporal

47 dimensions of OM-mineral interactions and associated transport processes, and their

48 impacts on source, composition and amount of OM accumulating on continental margins

49 and in the deep sea.

50 Radiocarbon $\left({ }^{14} \mathrm{C}\right)$ ages of OC residing in the surface mixed layer of shallow

51 continental shelf sediments are, in many cases, older than expected if the OM had

52 originated from modern-day biological production in the overlying water column or on

53 the adjacent land mass (Tao et al., 2015). These less-than-modern ${ }^{14} \mathrm{C}$ ages (i.e., $\Delta{ }^{14} \mathrm{C}<0$

$54 \%$ imply that there is a contribution of OM from petrogenic source(s), and/or that there

55 is a time offset between production and deposition of marine and/or terrestrially derived

56 biospheric OM.

57 Here we present a comprehensive assessment of the ${ }^{14} \mathrm{C}$ content of $\mathrm{OC}$ in both

58 bulk samples and specific grain size fractions of surface sediments from the northern

59 Chinese marginal seas (CMS), including the Bohai Sea, Yellow Sea and East China Sea

60 (Fig. 1A). The CMS is one of largest shallow marginal seas in the world where two major

61 rivers - the Yellow River and the Yangtze River - discharge vast quantities of sediment

$62\left(1.08\right.$ and $0.5 \times 10^{9} \mathrm{t} / \mathrm{yr}$, respectively; Yang et al., 2003, and reference in there) into an

63 extensive $(\sim 1000 \mathrm{~km}$ wide, $\sim 3000 \mathrm{~km}$ long) shallow shelf sea where, seasonal currents

64 and other hydrodynamic influence exert complex and dynamic controls on the sediment

65 distribution (Chen, 2009) (Fig. 2B). An extensive suite of more than 300 new ${ }^{14} \mathrm{C}$ and ${ }^{13} \mathrm{C}$

66 measurements are combined with previously published data to yield a detailed picture of

67 the spatial variability in OC characteristics for the CMS. When combined with 
sedimentological information, they shed new light on hydrodynamic controls on OC age

69 and distribution in this extensive marginal sea system.

\section{METHODS}

Surface sediments $(0-1,0-2$, or $0-5 \mathrm{~cm})$ were collected from the CMS during

72 different cruises (Table DR1 in the GSA Data Repository ${ }^{1}$ ). Particle size analysis was

73 performed on bulk sediments after freeze-drying and removal of OM $\left(350{ }^{\circ} \mathrm{C}\right.$ for $\left.12 \mathrm{~h}\right)$

74 using a Mastersizer 2000 (Malvern Instruments Ltd) laser-diffraction instrument

75 (Geological Institute, ETH-Zürich). For carbon isotopic analyses on size fractions, wet

76 sediment samples were separated into $<20,20-32$, and $32-63 \mu \mathrm{m}$ and coarser fractions

77 using stainless steel mesh sieves in less than one hour (in order to minimize OM losses).

78 Freeze-dried bulk sediment samples and corresponding grain size fractions were analyzed

79 for OC content and stable carbon isotopic composition at ETH Zürich. Prior to analysis,

80 inorganic carbon was removed from dried samples by fumigation with concentrated $\mathrm{HCl}$

$81(37 \%, 72 \mathrm{~h})$ and drying over $\mathrm{NaOH}$ pellets $(72 \mathrm{~h})$ in a desiccator at $60^{\circ} \mathrm{C}$. Radiocarbon

82 analysis was performed at the Laboratory of Ion Beam Physics, ETH Zürich.

\section{RESULTS}

84 Bulk OC ${ }^{14} \mathrm{C}$ contents $\left(\Delta^{14} \mathrm{C}_{\text {org }}\right)$ of surface sediments exhibit marked spatial

85 variability (avg. $-305 \% \mathrm{~m} \pm 102 \%$ o $(1 \sigma), \mathrm{n}=320$ ), with ${ }^{14} \mathrm{C}$-enriched, i.e., relatively young,

86 OC $(-174 \%$ to $-280 \%)$ in the central Yellow Sea and on the outer shelf of the East

87 China Sea, and older OC ( $-274 \%$ to $-682 \%$ ) along the inner edge of the East China

88 Sea, in front of the old and modern Yellow River delta and the Yangtze River delta, and

89 adjacent to the Island of Taiwan (Fig. 1; Table DR1). Total organic carbon (TOC)

90 contents of surface sediments vary from less than $0.01 \%$ to $2.14 \%$ (avg. $0.5 \% \pm 0.3(1 \sigma$ ), 
$91 \mathrm{n}=240$ ). Mean grain size of bulk sediments (Fig. 1C) varies from $6.2 \mu \mathrm{m}$ to $452.8 \mu \mathrm{m}$

$92 \quad$ (avg., $83.7 \mu \mathrm{m} ; \mathrm{n}=190$ ).

93 A subset of 16 samples spanning the nearshore regimes of the CMS was chosen

94 for separation and geochemical characterization of specific grain size fractions. The

95 samples (black symbols in Fig. 2B) were selected from regions that are proximal to the

96 mouths of the modern Yangtze and Yellow and old Yellow Rivers and also down-current

97 from these major river systems. Marked age variability is evident among grain size

98 fractions derived from the same surface sediment, with $\Delta{ }^{14} \mathrm{C}_{\mathrm{org}}$ values ranging from

$99-777 \%$ to $-218 \%(n=48)\left(\right.$ Table DR2). We also measured ${ }^{14} \mathrm{C}_{\text {org }}$ of coarser fractions

$100(63-125,125-250,250-500,>500 \mu \mathrm{m})$ in highly energetic regimes (at H20, H21, H23,

101 P01) with a large range of values $(-551 \% \pm 148 \%$; $n=11)$. Stable carbon isotope

102 compositions ( $\delta^{13} \mathrm{C}_{\text {org }}$ values $)$ also exhibit marked variability among grain size fractions

$103(-24.6 \%$ o to $-20.4 \%, \mathrm{n}=48)$. OC contents of grain size fractions ranged from $0.07 \%$ to

$1041.22 \%(\mathrm{n}=48)$, with smaller size fractions generally characterized by higher TOC values.

105 DISCUSSION

106 Hydrodynamic processes are considered to exert strong influence on the type,

107 amount, and dispersal of OC accumulating in sediments of the CMS (DeMaster et al.,

108 1985). The marked heterogeneity in $\Delta{ }^{14} \mathrm{C}_{\text {org }}$ values of surface sediments does not,

109 however, exhibit a straightforward relationship with grain size (Figs. 1B, 1C and 2A).

110 Hydrodynamic particle sorting would result in decreasing $\Delta{ }^{14} \mathrm{C}_{\mathrm{org}}$ values with increasing

111 grain size, and indeed, $\Delta{ }^{14} \mathrm{C}_{\mathrm{org}}$ values are negatively correlated with mean grain size for

112 offshore sediments (Fig. 2A, yellow and magenta, $>20 \mathrm{~m}$ water depth, $\mathrm{r}^{2}=0.53$ ). This

113 relationship may reflect various factors: diminished preservation of fresh OM on coarser 
114 particles due to lower mineral surface area protection (Aller, 1998), sluggish transport of

115 larger particles (Huettel et a., 2014), sediment winnowing processes (Hedges et al.,

116 1999), enhanced OM remineralization as a consequence of greater permeability of

117 coarser sediments (Huettel et al., 2014), or export of sedimentary rock-derived petrogenic

118 OC eroded from Taiwan island via episodic storm events (Hilton et al., 2008). Overall,

119 greater proportions of refractory OM from old carbon sources and protracted lateral

120 transport may account for the greater proportion of pre-aged OC in coarser fractions in

121 deeper waters.

122 In sharp contrast to this above trend, samples dominated by finer-grained

123 sediments (mean grain size, $<63 \mu \mathrm{m}$; Figure $2 \mathrm{~A}$, green and magenta symbols) do not

124 exhibit any correlation between grain size and $\Delta^{14} \mathrm{C}_{\mathrm{org}}\left(\mathrm{r}^{2}=0.1\right)$, and include a population

125 of samples characterized by significantly pre-aged OC (Fig. $2 \mathrm{~A}$, green, $\Delta^{14} \mathrm{C}_{\text {org }}$ values

$126<-250 \%$ ) with OC contents of up to $1.14 \%$. The latter observations may be partly

127 explained by fluvial supply of terrestrial materials containing fossil $\left({ }^{14} \mathrm{C}\right.$ dead $)$ or pre-

128 aged biospheric OC to the marginal seas (Tao et al., 2015). "Plumes" of aged OC

129 emanate from these point sources, dispersed by prevailing seasonal current systems in the

130 region (Fig. 1B). However, this cannot be the sole cause of this distribution pattern. For

131 instance, suspended OM from the Yangtze River mouth is characterized by higher $\Delta{ }^{14} \mathrm{C}_{\mathrm{org}}$

132 values $\left(\Delta^{14} \mathrm{C}_{\text {org }}\right.$ : $-103 \%$ to $-129 \%$, Wang et al., 2012$)$ relative to those of adjacent inner

133 shelf sediments. Similarly, the average reported $\Delta{ }^{14} C_{\text {org }}$ value of Yellow River particulate

134 OM collected across all seasons is $-417 \% \pm 17 \%$ (Tao et al., 2015), while in the

135 corresponding deltaic area, we found that $\Delta{ }^{14} \mathrm{C}_{\text {org }}$ values of $20-32 \mu \mathrm{m}$ fraction are lower

136 (-604\%o at B45). The contrast in OC ages between shallow (inner) and deeper (outer) 
137 shelves may reflect the influence of hydrodynamic processes where differential particle

138 transport and inherent $\Delta{ }^{14} \mathrm{C}_{\text {org }}$ variations among grain size fractions impart changes in

139 bulk sediment characteristics.

140 Finer-grained sediments characterized by older OC (Fig. 2A green) derived

141 mostly from shallow inner shelf and subaqueous delta environments that are prone to

142 wind- and tidally-driven sediment resuspension processes (Wang et al., 2011, Yang et al.,

143 2011) (Fig. 2B). Local and regional currents mobilize, entrain and redistribute sediments

144 (Chen, 2009), satellite images (Fig. DR1) clearly showing trajectories of large-scale

145 sediment dispersal. In winter, Yangtze-derived fine-grained sediments are carried

146 southward in the bottom layers by an intensified Chinese Coastal Current, transporting

147 materials parallel to the coastline, forming the muddy regimes (Liu et al., 2007; Yang et

148 al., 2011). These seasonal currents induce sediment sorting, and ${ }^{14} \mathrm{C}$ analyses of OC

149 residing in different grain size fractions were undertaken on representative samples $(\mathrm{n}=$

150 16) from shallow regions $(<50 \mathrm{~m})$ in an effort to understand hydrodynamic controls on

151 the scatter exhibited in mean grain and $\Delta{ }^{14} C_{\text {org }}$ values in finer-grained sediments $(<63$

$152 \mu \mathrm{m}$; Figure $2 \mathrm{~B}$, green). For several locations $(\mathrm{n}=12)$, it is evident that the $20-32 \mu \mathrm{m}$

153 fraction exhibits lower $\Delta{ }^{14} \mathrm{C}_{\mathrm{org}}$ than corresponding smaller $(<20 \mu \mathrm{m})$ and larger $(>32 \mu \mathrm{m})$

154 fractions (Fig. 3B, $t$-test, $p<0.05$ ). For example, at a Yellow River pro-delta location

155 (station: B45), the $\Delta{ }^{14} \mathrm{C}_{\text {org }}$ values of this fraction are $\sim 255 \%$ and $220 \%$ o lower $\left(\sim 4000{ }^{14} \mathrm{C}\right.$

$156 \mathrm{yr}$ older) than those of $<20 \mu \mathrm{m}$ and $32-63 \mu \mathrm{m}$ fractions, respectively (Table DR2). In

157 some highly energetic regimes local conditions may mobilize of coarser materials. For

158 example, in the Yangtze River prodelta (P01) and the region $200 \mathrm{~km}$ northward (e.g.,

$159 \mathrm{H} 20, \mathrm{H} 21, \mathrm{H} 23)$ where wave and tidal action promotes vigorous sediment resuspension 
160 (Wang et al., 2011), $\Delta{ }^{14} \mathrm{C}_{\text {org }}$ values of coarser fractions (e.g., 32-63 $\mu \mathrm{m}$ ) are lower than 161 corresponding 20-32 $\mu \mathrm{m}$ fractions (Fig. DR2b). The theoretical relationship between

162 critical shear stress and grain size of spherical quartz implies that particle sizes centered

163 around $20 \mu \mathrm{m}$ have the greatest potential to be eroded and remobilized when compared

164 with the more cohesive clay fractions and the coarser silt and sand fractions (Thomsen

165 and Gust, 2000; McCave and Hall, 2006; Fig. 3A). This corresponds to the "sortable silt"

166 fraction $(10-63 \mu \mathrm{m})$ as defined by McCave and Hall (2006). For practical purposes (i.e.,

167 sieve mesh sizes), we adopt a slightly narrower range $(20-63 \mu \mathrm{m})$ here. The relatively

$168{ }^{14} \mathrm{C}$-depleted values of $\mathrm{OM}$ associated with this "sortable silt" fraction in subaqueous

169 delta and inner shelf sediments of the CMS are consistent with the influence of particle

170 resuspension processes. Systematic ${ }^{14} \mathrm{C}$ relationships between the sortable silt and other

171 grain size fractions are evident in 12 samples $(t$-test, $p<0.05)$, but they do not hold

172 across the entire suite of samples investigated $(p>0.05)$. This is likely due to the wide

173 diversity of depositional environments in which other factors such as particle density and

174 shape, and flow viscosity, and particle interactions (e.g., aggregation) may play a role

175 (Thomsen and Gust, 2000).

176 As remobilized particles enter the bottom boundary layer (BBL), they may

177 contribute to the formation of benthic nepheloid layers (BNLs) that can persist for

178 extended periods of time and result in translocation of entrained particles over

179 considerable distances prior to eventual sedimentation and burial. In the Yellow River

180 delta and in the adjacent Bohai Sea, winter storm waves and tidal currents induce

181 enhanced sediment resuspension (up to $100 \mathrm{mg} / \mathrm{l}$ in the BBL; Yang et al., 2011).

182 Enhanced BBL sediment transport on the East China Sea inner shelf has also been 
183 indicated from modeling studies (Bian et al., 2013) and observations (Li et al., 2013). The

184 BBL is characterized by significant physical, chemical and biological gradients that

185 promote oxic degradation and transformation of labile OM (Keil et al., 2004; Thomsen

186 and Gust, 2000). While it is not known if BBL processes preferentially act upon materials

187 residing in the sortable silt fraction, residual OM within this fraction is likely to become

188 more refractory and increase in ${ }^{14} \mathrm{C}$ age as a consequence of its protracted residence in the

189 BNL and participation in repeated sediment resuspension-deposition cycles (Aller, 1998;

190 Aller and Blair, 2004). Notably, the pattern of $\delta^{13} \mathrm{C}_{\text {org }}$ values among grain size fractions

191 echoes that of $\Delta{ }^{14} \mathrm{C}_{\text {org }}$, with relatively low values for the $20-32 \mu \mathrm{m}$ fraction (Fig. 3C; $p$

$192<0.01)$. This suggests that during resuspension and lateral transport the sortable silt

193 fraction loses OC (Fig. 3D) and retains a greater proportion of ${ }^{13} \mathrm{C}$-depleted $\mathrm{OC}$ due to

194 preferential mobilization of terrestrial material, selective loss of marine OC relative to

195 terrestrial OC, or enhanced degradation of ${ }^{13} \mathrm{C}$-enriched marine OM (e.g., hydrolysable

196 amino acids, carbohydrates) relative to more refractory ${ }^{13} \mathrm{C}$-depleted marine $\mathrm{OM}$

197 components (Hwang and Druffel, 2003). Prevailing and seasonally oscillating coastal

198 currents transport and disperse entrained sediment both northward and southward in the

199 CMS (Chen, 2009), with attendant degradation processes promoting attenuation, aging

200 and ${ }^{13} \mathrm{C}$-depletion of associated OM. In offshore and deeper water settings, relatively high

$201 \Delta \Delta^{14} \mathrm{C}_{\text {org }}$ values suggest translocation of sediments to distal regions of the CMS by other

202 processes (e.g., near-surface transport; Milliman et al., 1985; Chen, 2009) or direct

203 supply from overlying waters. With respect to the latter, the muddy area southwest of

204 Cheju Island, may reflect vertical settling and accumulation of marine OM, as supported 
205 by observations of higher chlorophyll- $a$ concentrations in surface waters (Fu, et al., 2015)

206 and higher $\delta^{13} \mathrm{C}$ values of underlying sediments (data not shown).

207 Overall, our investigation reveals that marked spatial heterogeneity exists in ${ }^{14} \mathrm{C}$

208 ages of bulk OC and in grain size fractions from surface sediments of the CMS. This

209 heterogeneity reflects both modern and relict material, and sedimentological influences

210 on OC content and composition. Enrichment of aged OC in the sortable silt fraction of

211 inner shelf sediments is attributed to cyclic resuspension-deposition processes occurring

212 within the BBL. These results shed new light on processes that control the fate and

213 composition of OM delivered to and produced in continental shelf seas, and have

214 implications for carbon cycling and burial in other shallow marginal sea systems (e.g.,

215 Dauwe and Middelburg, 1998). With respect to the latter, aging and chemical

216 transformations of OC on shallow and wide continental shelves will confound

217 assessments of OC burial based on simple isotopic mixing models. Assignment of end-

218 members based on $\Delta^{14} \mathrm{C}$ or $\delta^{13} \mathrm{C}$ values of bulk OC and/or specific molecular tracers of

219 source carbon pools may fail to account for these processes during transport, leading to

220 potential errors in source apportionment, and in corresponding budgets for OM burial.

221 These processes may also lead to aliasing in organic geochemical proxies in sedimentary

222 records. Moreover, since the degree of transport-associated aging likely varies with sea

223 level stand due to changing time- and length-scales of sediment resuspension and

224 redistribution, the magnitude of temporal and spatial offsets between proxy signals

225 associated with different sedimentary phases may also vary. Such processes occurring in

226 continental shelf seas also likely influence the nature of sedimentary OM that is

227 ultimately exported to and buried in sediments accumulating in adjacent ocean basins. 
228 Indeed, sediment and OC redistribution is by no means restricted to shallow marginal 229 seas (McCave and Hall, 2006; Inthorn et al., 2006).

230 OM-mineral interactions play a key role on continental shelves, influencing OM

231 reactivity and hydrodynamic properties. Protracted sediment entrainment in cyclic

232 resuspension-deposition loops enhances remineralization of OC, prompting these systems

233 to serve as sources for carbon to the atmosphere, while the refractory OC that escapes

234 remineralization is likely to serve as a long-term carbon sink. Overall, the net influence of

235 sediment redistribution processes over continental margins on the carbon cycle, and on

236 continental margin and deep ocean sedimentary archives remains poorly understood, as

237 does the manner in which it may vary under changing ocean and climate conditions.

\section{ACKNOWLEDGMENTS}

This work was supported by SNF “CAPS-LOCK” project 200021_140850

240 (Eglinton), by the National Natural Science Foundation of China (grants 41520104009

241 and 41521064 to Zhao) and by "111" project (B13030). We thank the reviewers for

242 comments on the manuscript.

\section{REFERENCES CITED}

244 Aller, R.C., 1998, Mobile deltaic and continental shelf muds as suboxic, fluidized bed 245 reactors: Marine Chemistry, v. 61, p. 143-155, doi:10.1016/S0304-4203(98)00024$246 \quad 3$

247 Aller, R.C., and Blair, N.E., 2004, Early diagenetic remineralization of sedimentary 248 organic C in the Gulf of Papua deltaic complex (Papua New Guinea): net loss of 249 terrestrial $\mathrm{C}$ and diagenetic fractionation of $\mathrm{C}$ isotopes: Geochimica et 250 Cosmochimica Acta, v. 68, p. 1815-1825, doi:10.1016/j.gca.2003.10.028. 
Bian, C.W., Jiang, W.S., Greatbatch, R.J., and Ding, H., 2013, The suspended sediment concentration distribution in the Bohai Sea, Yellow Sea and East China Sea: Journal of Ocean University of China, v. 12, p. 345-354, doi:10.1007/s11802-013-1916-3.

Burdige, D.J., 2005, Burial of terrestrial organic matter in marine sediments: A reassessment: Global Biogeochemical Cycles, v. 19, p. 1-7, doi:10.1029/2004GB002368.

Chen, C.-T.A., 2009, Chemical and physical fronts in the Bohai, Yellow and East China seas: Journal of Marine Systems, v. 78, p. 394-410, doi:10.1016/j.jmarsys.2008.11.016.

Dauwe, B., and Middelburg, J.J., 1998, Amino acids and hexosamines as indicators of organic matter degradation state in North Sea sediments: Limnology and Oceanography, v. 43, p. 782-798, doi:10.4319/1o.1998.43.5.0782.

DeMaster, D.J., McKee, B.A., Nittrouer, C.A., Jiangchu, Q., and Guodong, C., 1985, Rates of sediment accumulation and particle reworking based on radiochemical measurements from continental shelf deposits in the East China Sea: Continental Shelf Research, v. 4, p. 143-158, doi:10.1016/0278-4343(85)90026-3.

Deng, B., Zhang, J., and Wu, Y., 2006, Recent sediment accumulation and carbon burial in the East China Sea: Global Biogeochemical Cycles, v. 20, p. 1-12, doi:10.1029/2005GB002559.

Fu, D.Y., Huang, Z.J., Zhang, Y.Z., Pan, D.L., Ding, Y.Z., Liu, D.Z., Zhang, Y., Mao, Z.H., and Chen, J.F., 2015, Factors affecting spring bloom in the South of Cheju Island in the East China Sea: Acta Oceanologica Sinica, v. 34, p. 51-58, doi:10.1007/s13131-015-0633-8. 
Hedges, J.I., Hu, F.S., Devol, A.H., Hartnett, H.E., Tsamakis, E., and Keil, R.G., 1999, Sedimentary organic matter preservation: A test for selective degradation under oxic conditions: American Journal of Science, v. 299, p. 529-555, doi:10.2475/ajs.299.79.529.

Hilton, R.G., Galy, A., Hovius, N., Chen, M.C., Horing, M.J., and Chen, H., 2008, Tropical-cyclone-driven erosion of the terrestrial biosphere from mountains: Nature Geoscience, v. 1, p. 759-762, doi:10.1038/ngeo333.

Huettel, M., Berg, P., and Kostka, J.E., 2014, Benthic Exchange and Biogeochemical Cycling in Permeable Sediments: Annual Review of Marine Science, v. 6, p. 23-51, doi:10.1146/annurev-marine-051413-012706.

Hwang, J., and Druffel, E.R., 2003, Lipid-like material as the source of the uncharacterized organic carbon in the ocean?: Science, v. 299, p. 881-884, doi:10.1126/science.1078508.

Inthorn, M., Wagner, T., Scheeder, G., and Zabel, M., 2006, Lateral transport controls distribution, quality and burial of organic matter along continental slopes in highproductivity areas: Geology, v. 34, p. 205-208, doi:10.1130/G22153.1.

Keil, R.G., Dickens, A.F., Arnarson, T., Nunn, B.L., and Devol, A.H., 2004, What is the oxygen exposure time of laterally transported organic matter along the Washington margin?: Marine Chemistry, v. 92, p. 157-165, doi:10.1016/j.marchem.2004.06.024.

Kennedy, M.J., and Wagner, T., 2011, Clay mineral continental amplifier for marine carbon sequestration in a greenhouse ocean: Proceedings of the National Academy of Sciences of the United States of America, v. 108, p. 9776-9781, doi:10.1073/pnas. 1018670108 . 
Li, Y.H., Qiao, L., Wang, A., Zhang, Y., Fang, J.Y., and Chen, J., 2013, Seasonal variation of water column structure and sediment transport in a mud depo-center off the Zhejiang-Fujian coast in China: Ocean Dynamics, v. 63, p. 679-690, doi:10.1007/s10236-013-0620-6.

301 Liu, J.P., Xu, K.H., Li, A.C., Milliman, J.D., Velozzi, D.M., Xiao, S.B., and Yang, Z.S., 302 2007, Flux and fate of Yangtze River sediment delivered to the East China Sea:

303 Geomorphology, v. 85, p. 208-224, doi:10.1016/j.geomorph.2006.03.023.

304 McCave, I., and Hall, I., 2006, Size sorting in marine muds: Processes, pitfalls, and 305 prospects for paleoflow-speed proxies: Geochemistry Geophysics Geosystems, v. 7, 306 p. 1-37, doi:10.1029/2006GC001284.

307 Milliman, J., Beardsley, R.C., Yang, Z.S., and Limeburner, R., 1985, Modern Huanghe308 derived muds on the outer shelf of the East China Sea: Identification and potential 309 transport mechanisms: Continental Shelf Research, v. 4, p. 175-188, $310 \quad$ doi:10.1016/0278-4343(85)90028-7.

311 Qiao, S.Q., Yang, Z.S., Liu, J.P., Sun, X.X., Xiang, R., Shi, X.F., Fan, D.J., and Saito, Y., 312 2011, Records of late-Holocene East Asian winter monsoon in the East China Sea: 313 Key grain-size component of quartz versus bulk sediments: Quaternary International, 314 v. 230 , p. 106-114, doi:10.1016/j.quaint.2010.01.020.

315 Tao, S., Eglinton, T.I., Montluçon, D.B., McIntyre, C., and Zhao, M., 2015, Pre-aged soil 316 organic carbon as a major component of the Yellow River suspended load: Regional 317 significance and global relevance: Earth and Planetary Science Letters, v. 414, p. 77$318 \quad$ 86, doi:10.1016/j.eps1.2015.01.004. 
319 Thomsen, L., and Gust, G., 2000, Sediment erosion thresholds and characteristics of 320 resuspended aggregates on the western European continental margin: Deep-sea

321 Research. Part I, Oceanographic Research Papers, v. 47, p. 1881-1897, 322 doi:10.1016/S0967-0637(00)00003-0.

323 Wang, X.C., Ma, H., Li, R., Song, Z., and Wu, J., 2012, Seasonal fluxes and source 324 variation of organic carbon transported by two major Chinese Rivers: The Yellow 325 River and Changjiang (Yangtze) River: Global Biogeochemical Cycles, v. 26, p. 1$326 \quad$ 10, doi:10.1029/2011GB004130.

327 Wang, X.H., Qiao, F.L., Lu, J., and Gong, F., 2011, The turbidity maxima of the northern 328 Jiangsu shoal-water in the Yellow Sea, China: Estuarine, Coastal and Shelf Science, v. 93, p. 202-211, doi:10.1016/j.ecss.2010.10.020.

330 Yang, S.Y., Jung, H.S., Lim, D.I., and Li, C.X., 2003, A review on the provenance 331 discrimination of sediments in the Yellow Sea: Earth-Science Reviews, v. 63, p. 93120, doi:10.1016/S0012-8252(03)00033-3.

333 Yang, Z.S., Ji, Y.J., Bi, N.S., Lei, K., and Wang, H.J., 2011, Sediment transport off the 334 Huanghe (Yellow River) delta and in the adjacent Bohai Sea in winter and seasonal comparison: Estuarine, Coastal and Shelf Science, v. 93, p. 173-181, doi:10.1016/j.ecss.2010.06.005.

\section{FIGURE CAPTIONS}

338 Figure 1. Geographical variations in bulk properties of surface sediments in the Chinese 339 marginal seas (CMS). A: Total organic carbon (TOC) (\%). B:) $\Delta^{14} \mathrm{C}_{\text {org }}(\%$ ). C: Mean 340 grain size $(\mu \mathrm{m})$. Black dots represent sample locations. Areas of fine-grained sediment 
accumulation (red-colored regions in C) match well with those delineated by Qiao et al.

342 (2011).

344 Figure 2. Sedimentological control on bulk total organic carbon (TOC) (\%) and $\Delta{ }^{14} \mathrm{C}_{\mathrm{org}}$

345 (\%) in surface sediments from the Chinese marginal seas (CMS). A: Relationship

346 between $\Delta{ }^{14} \mathrm{C}_{\text {org }}$ and mean grain size for surface sediments. Circle size represents

347 approximate \% TOC. Green, yellow and magenta circles represent samples with mean

348 grain size of $<63 \mu \mathrm{m}$ and $\Delta{ }^{14} \mathrm{C}_{\mathrm{org}}<-250 \%$ (green), mean grain size $<63 \mu \mathrm{m}$ and $\Delta{ }^{14} \mathrm{C}_{\mathrm{org}}$

$349>-250 \%$ (magenta), and mean grain size $>63 \mu \mathrm{m}$ (yellow). Vertical green bar highlights

350 those samples with a mean grain size $<63 \mu \mathrm{m}$, including those that exhibit depleted

$351 \Delta \Delta^{14} \mathrm{C}_{\mathrm{org}}$ values. B: Locations of the three corresponding sample types. Inner-shelf and

352 highly energetic regime samples selected for geochemical analysis of grain size fractions

353 are highlighted by black circles $(n=12)$ and squares $(n=4)$, respectively. Regional

354 circulation patterns are also shown with white arrows indicating the inferred current

355 directions and bathymetric contours (modified from Chen, 2009; Liu et al., 2007).

357 Figure 3. A: Black line shows the idealized behavior of bed shear stress ( $y$ axis) as a 358 function of grain size ( $x$ axis) (modified from McCave and Hall, 2006), and green and red 359 curves highlight $10-63$ and $20-32 \mu \mathrm{m}$ grain size ranges, respectively. Box and whisker 360 plots showing $\Delta^{14} \mathrm{C}_{\text {org }}(\mathrm{n}=12$; Figure $2 \mathrm{~B}$, samples denoted with black circles $)(\mathrm{B}), \delta^{13} \mathrm{C}_{\mathrm{org}}$ $361(n=16)(C)$, and total organic cabon (TOC \%) values $(n=16)(D)$ of $<20,20-32$, and $362 \quad 32-63 \mu \mathrm{m}$ grain size fractions in surface sediments from shallow, near-shore regions of 363 the Chinese marginal seas (CMS) (Fig. 2B). Dashed and solid horizontal lines in the box 
364 indicate mean and median value, respectively; upper/lower " $\mathrm{x}$ " symbols and box

365 represent $1 \%$ and $99 \%, 25 \%$, and $75 \%$ statistics. Letters $(a, b, c)$ above the boxes indicate 366 a significant statistical difference at the level of $p<0.05$.

367

368 1GSA Data Repository item 2016xxx, xxxxxxxx, is available online at

369 www.geosociety.org/pubs/ft2016.htm, or on request from editing@geosociety.org or

370 Documents Secretary, GSA, P.O. Box 9140, Boulder, CO 80301, USA. 


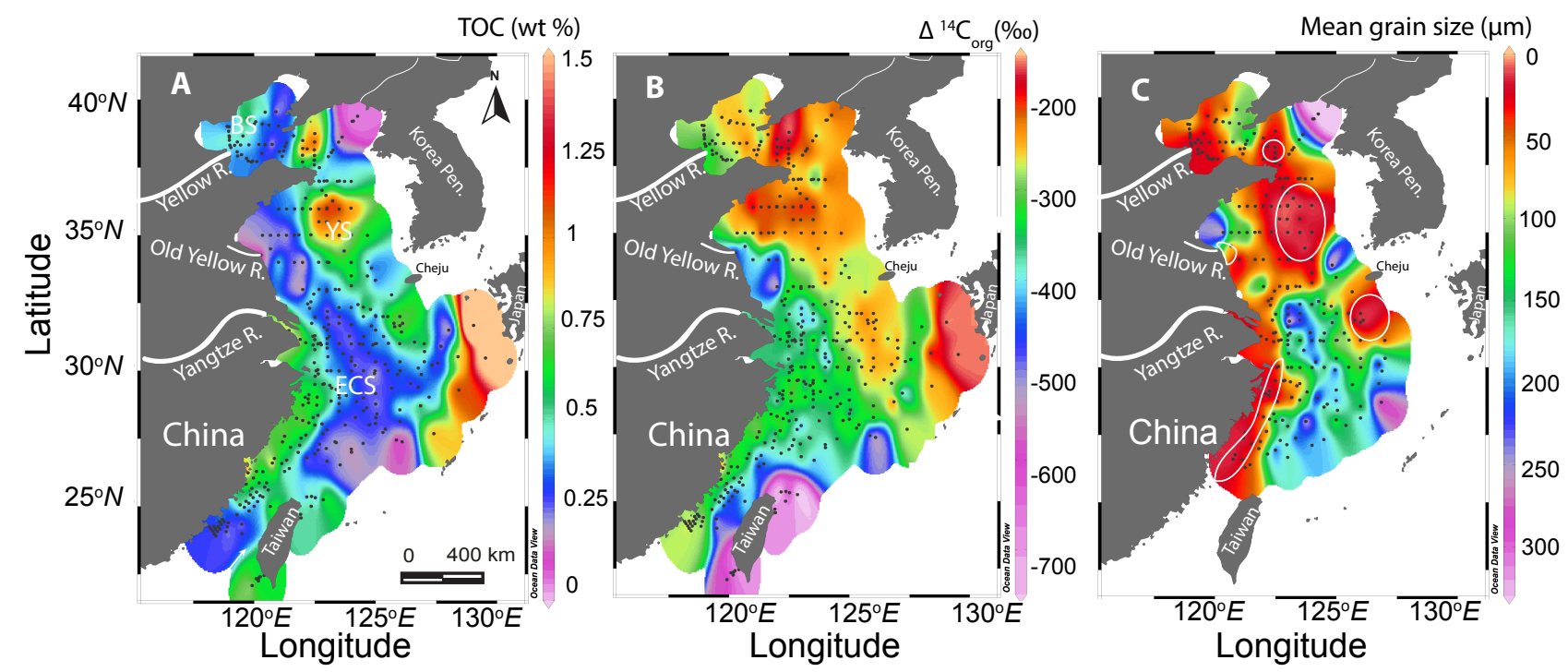




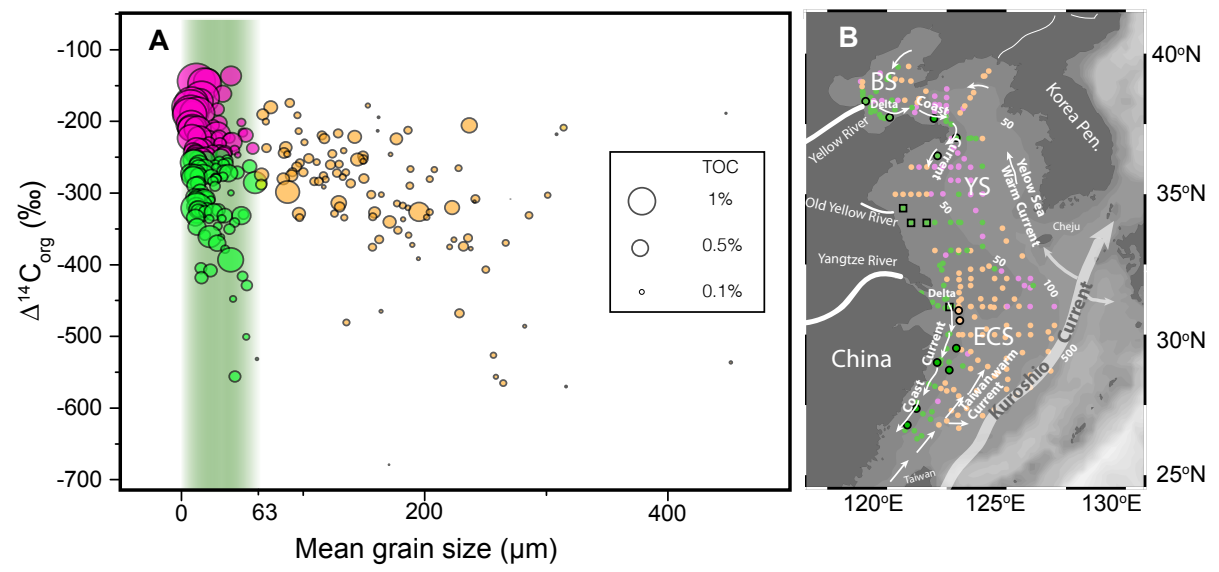




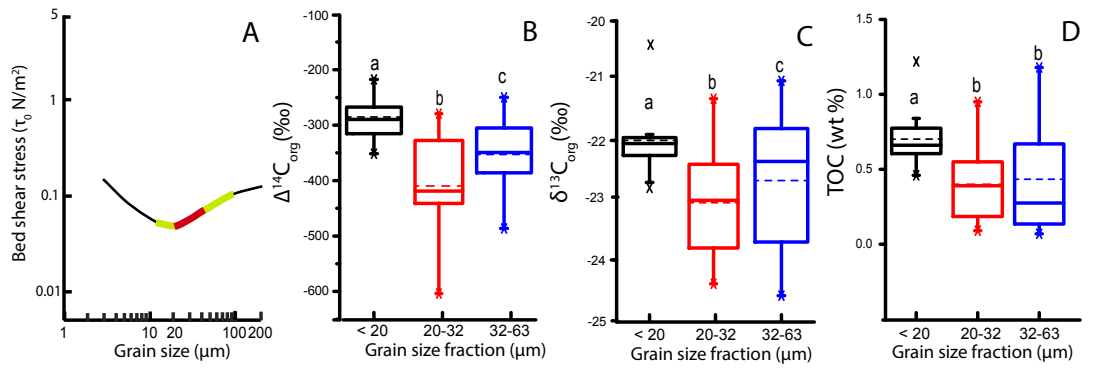




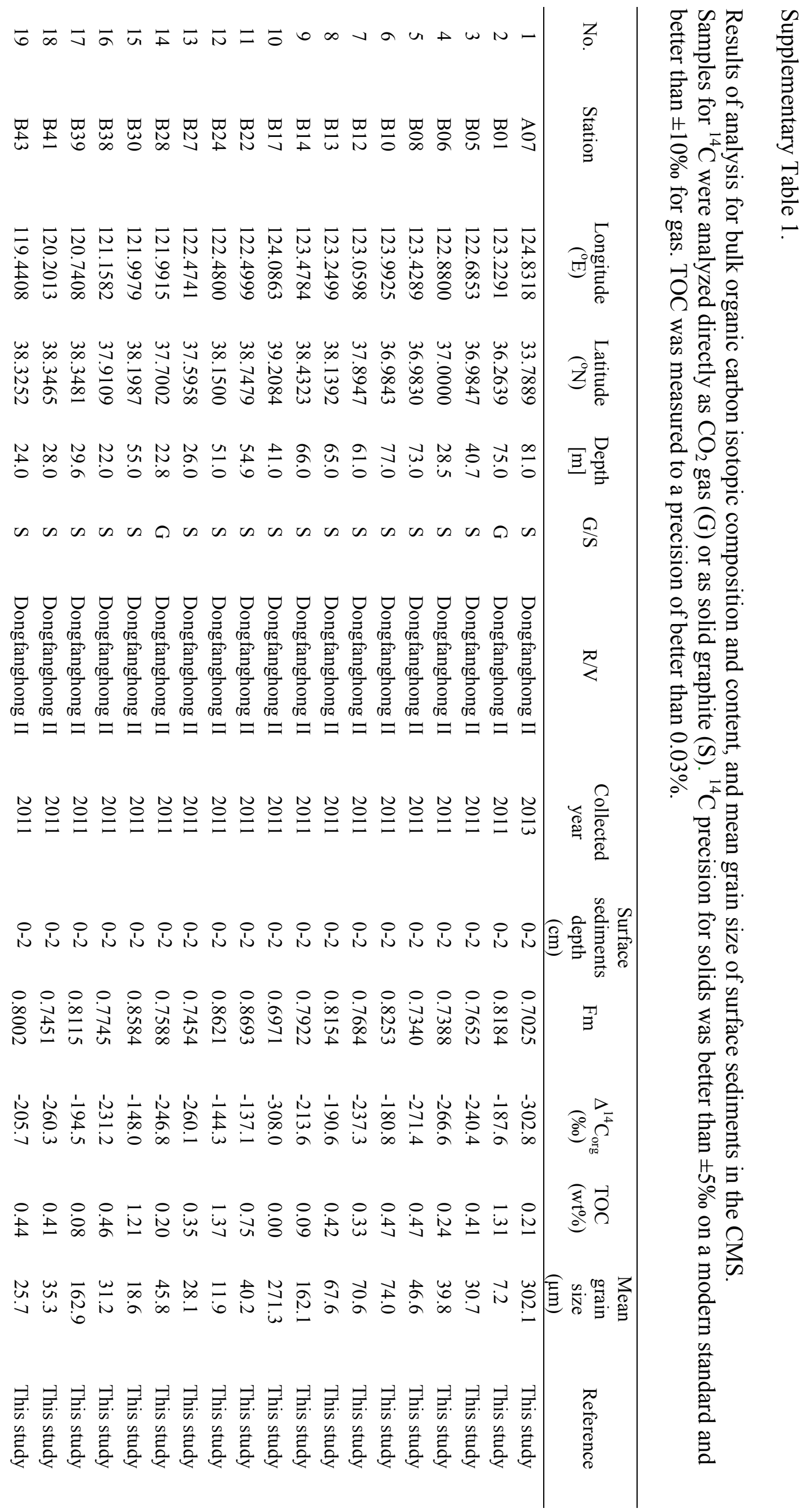




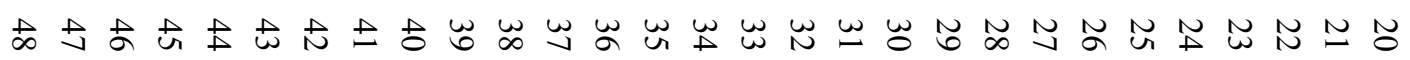

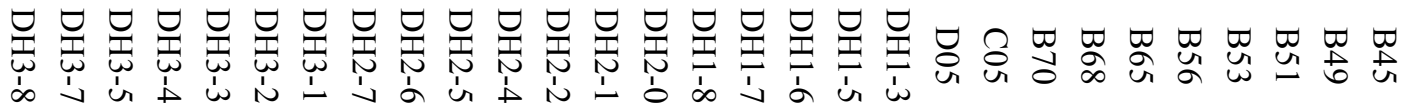

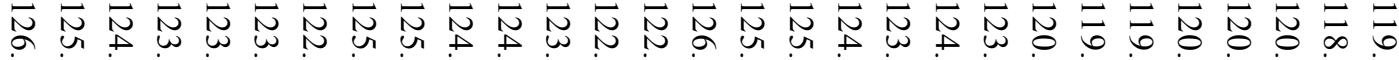

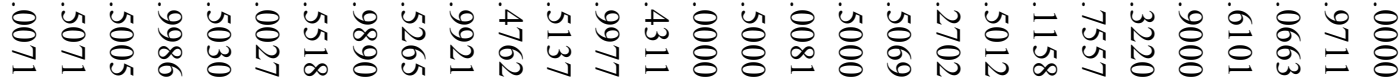

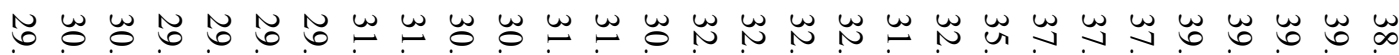

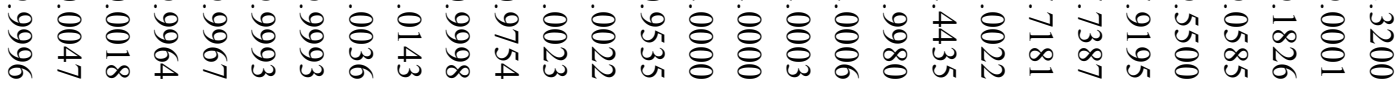
जि

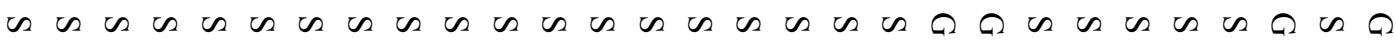

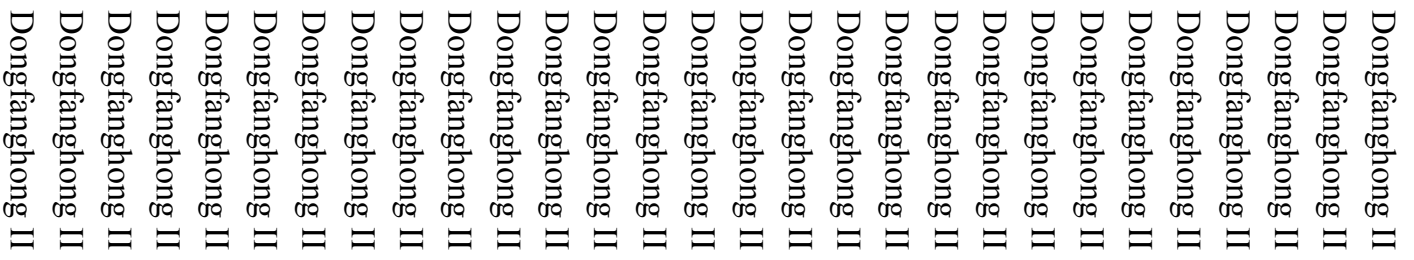

응 苍 N

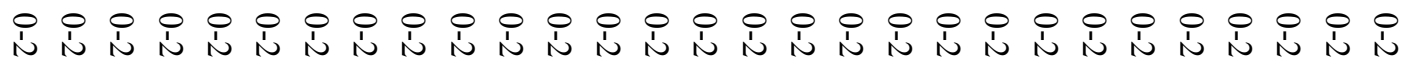

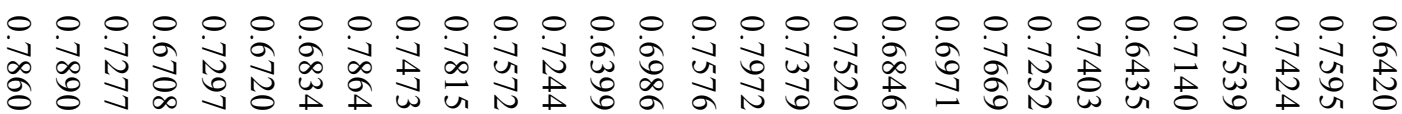

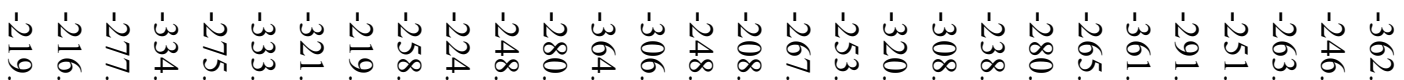

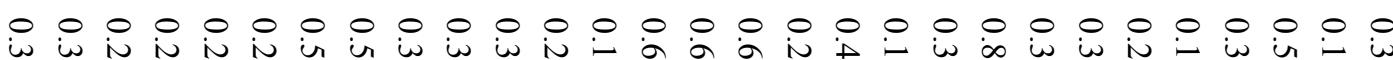

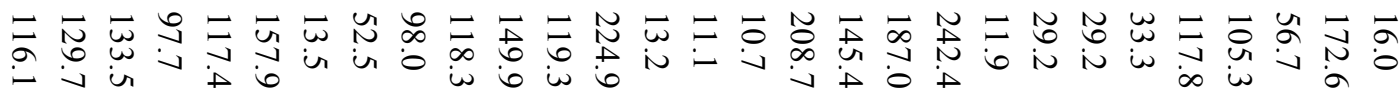

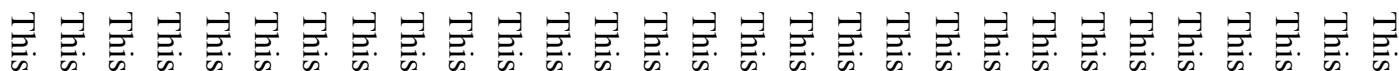

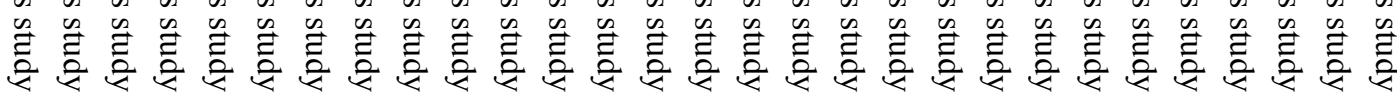




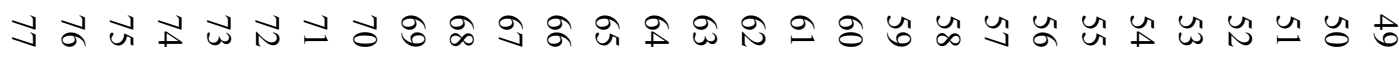

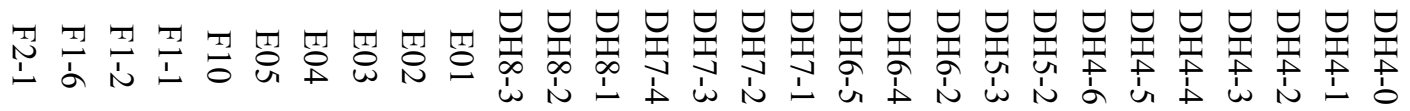

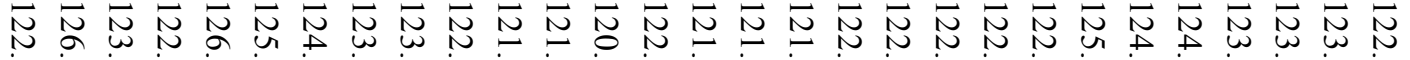

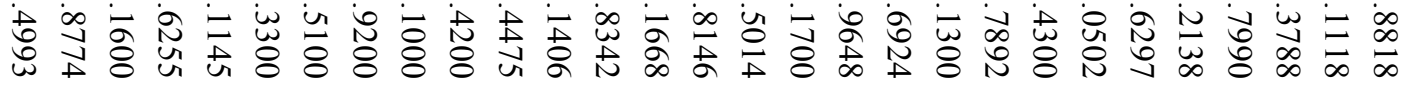

가

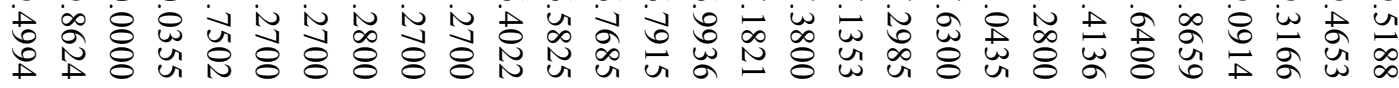

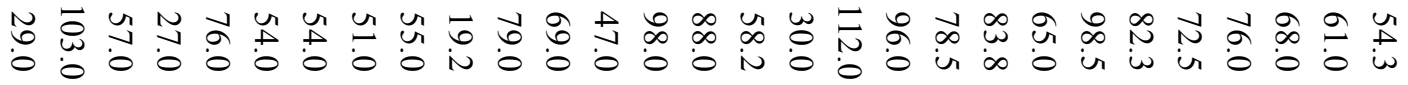

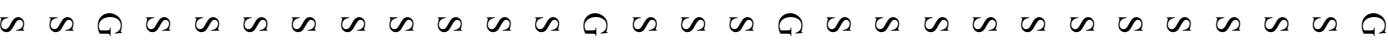

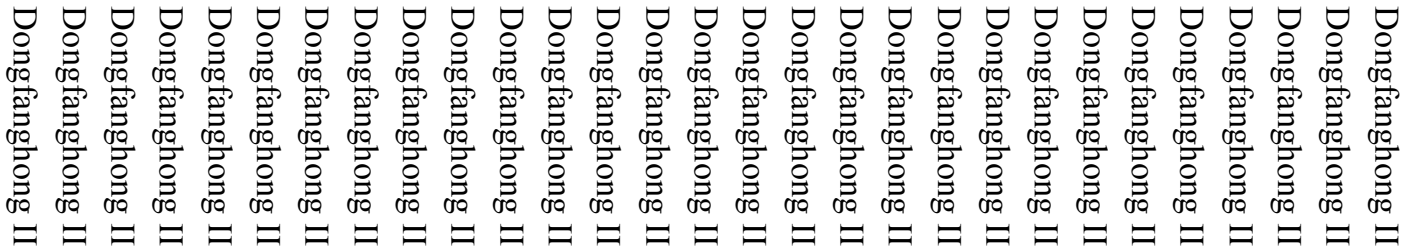

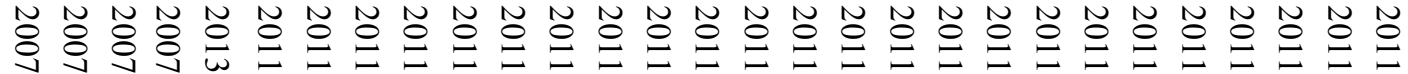

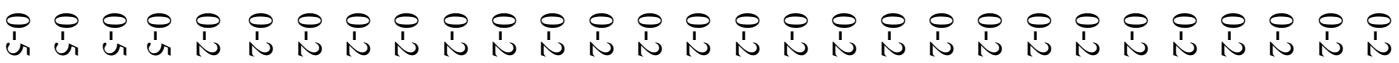

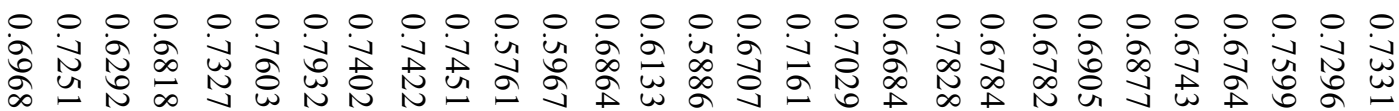

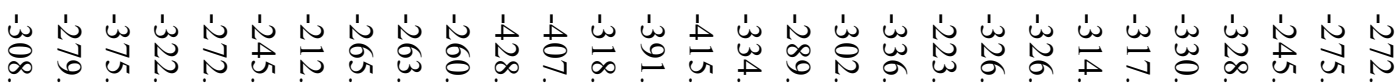

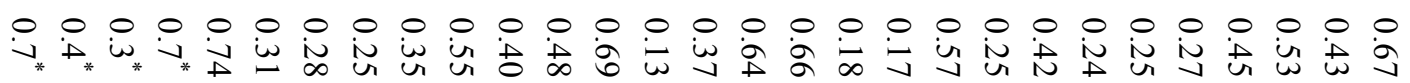

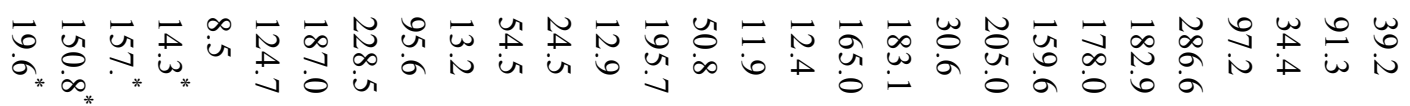

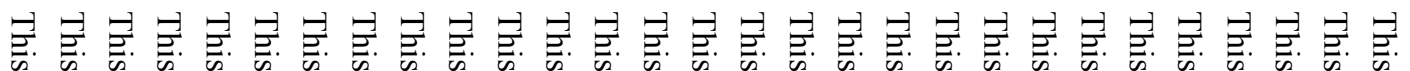

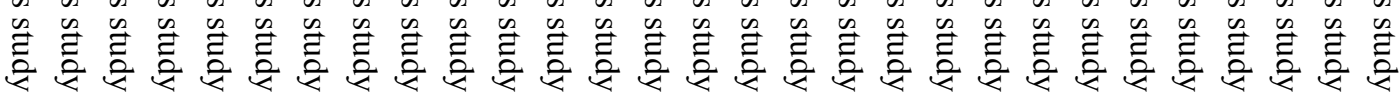




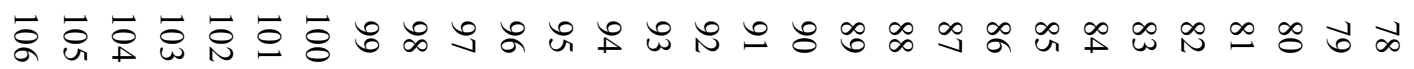

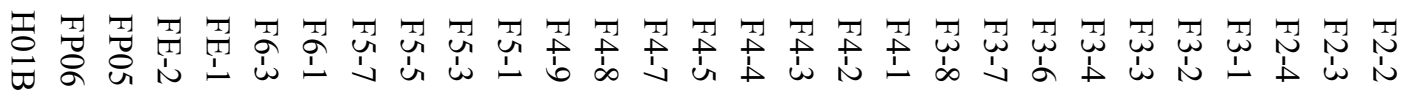

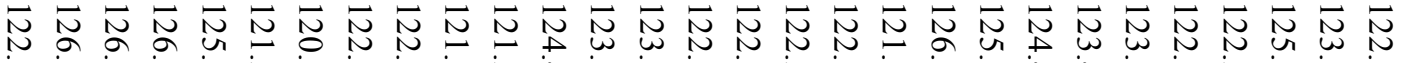

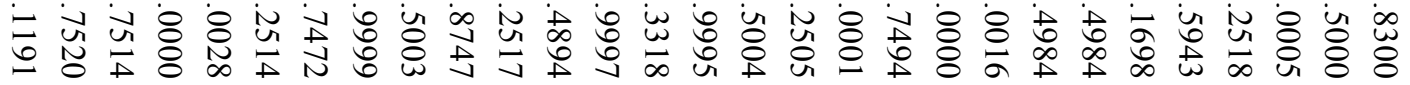

బ

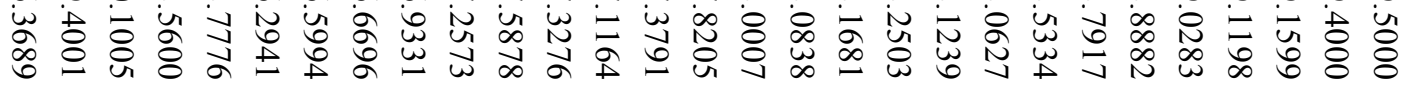

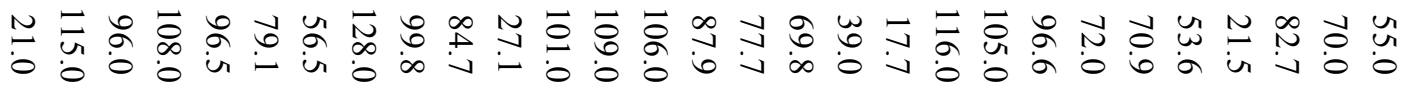

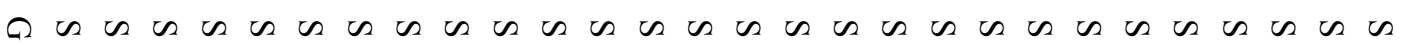

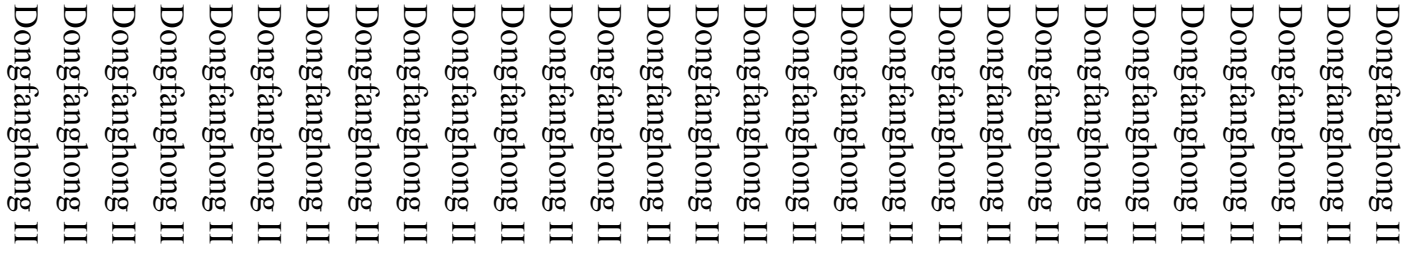

N

I

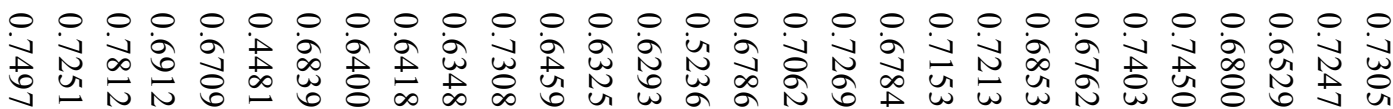

菂

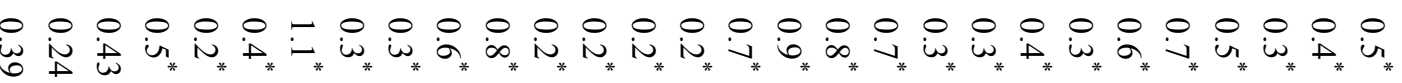

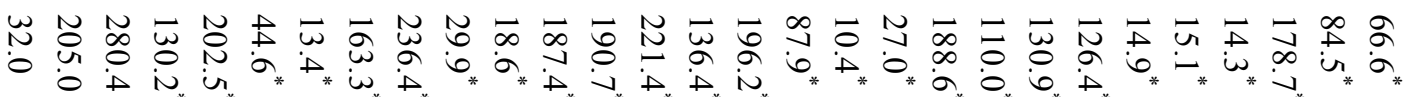

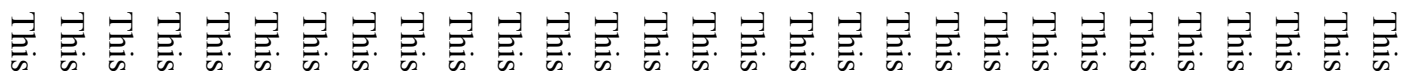

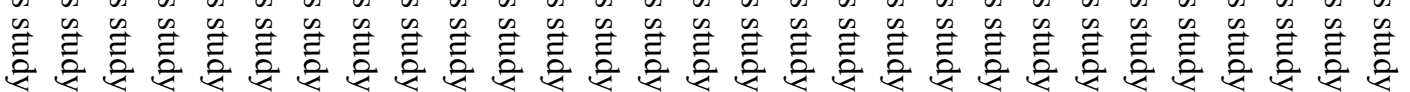




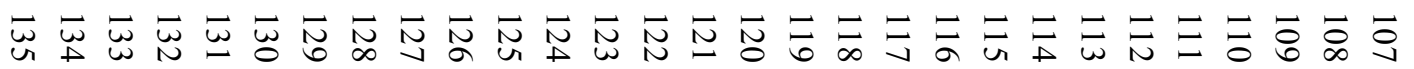

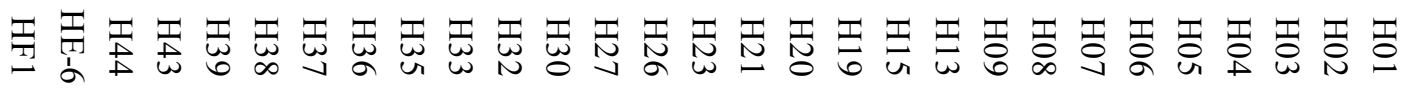

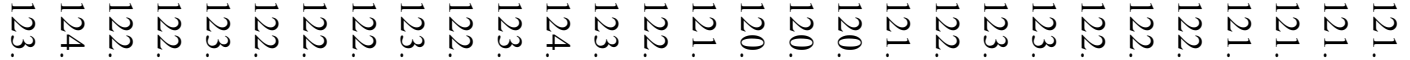

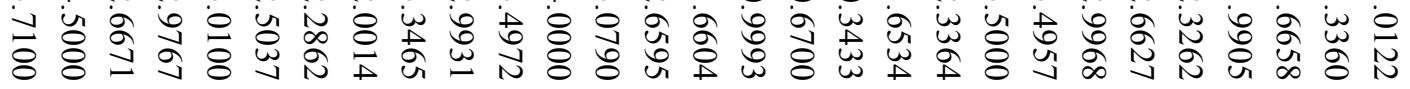

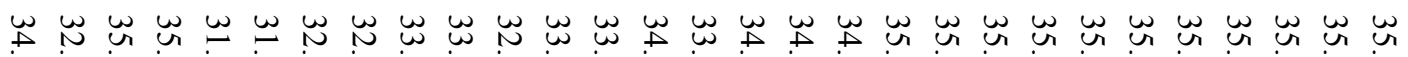

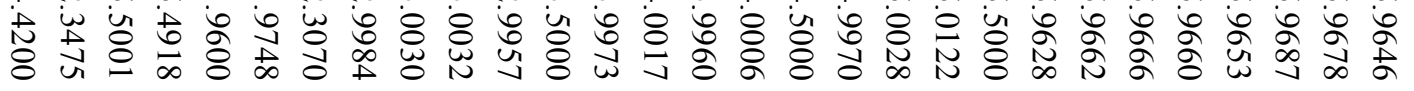


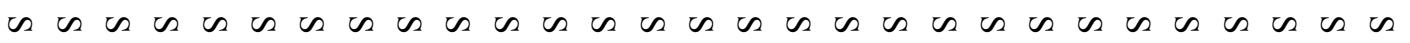

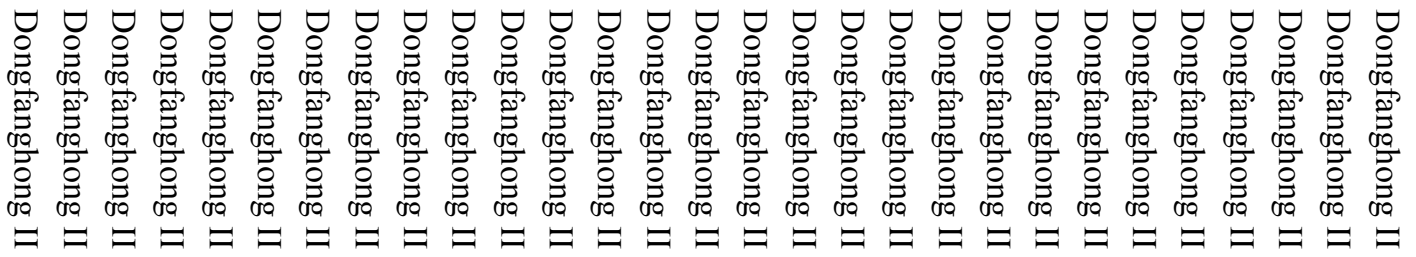

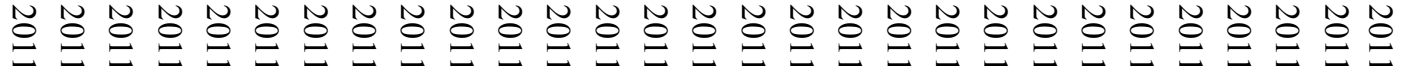

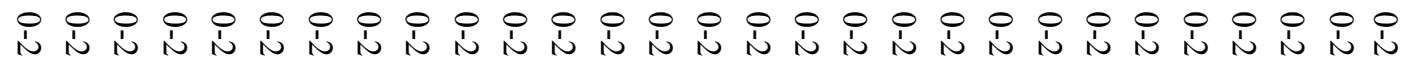

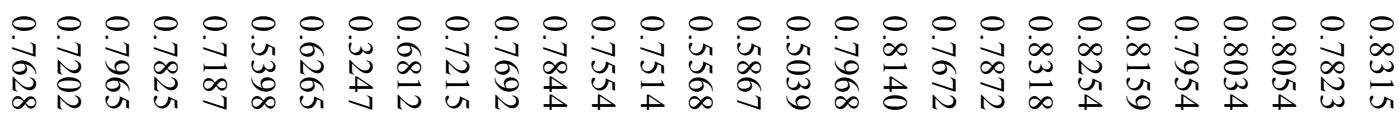

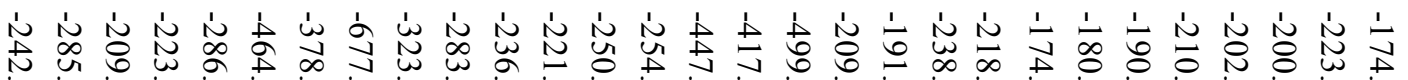

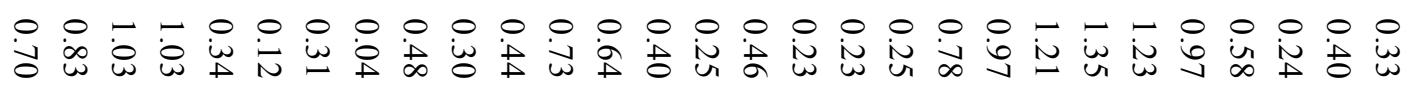

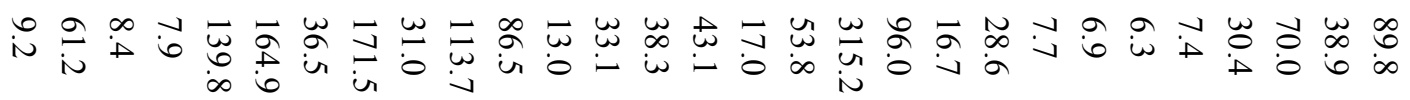

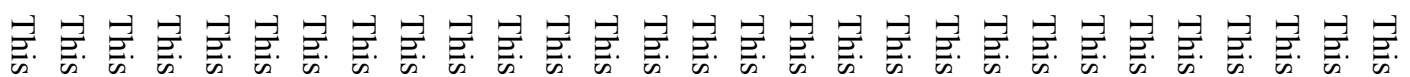

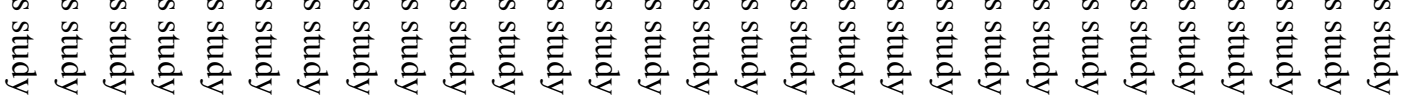




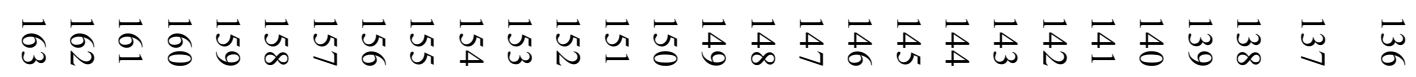

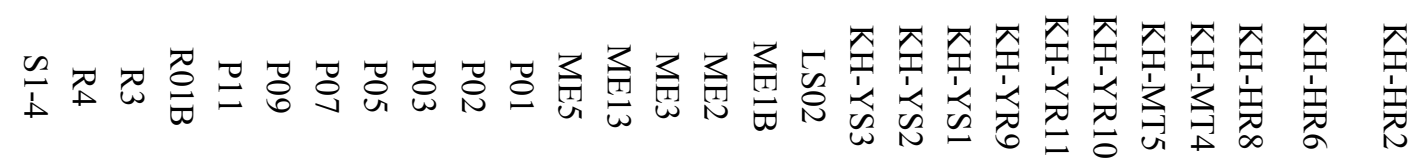

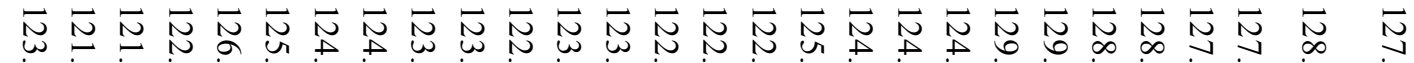

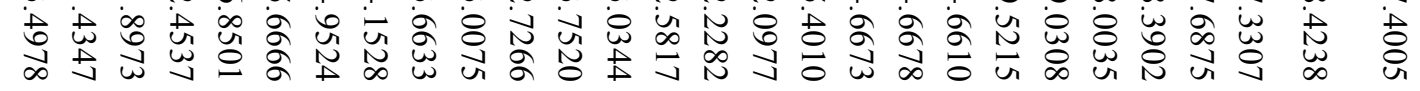

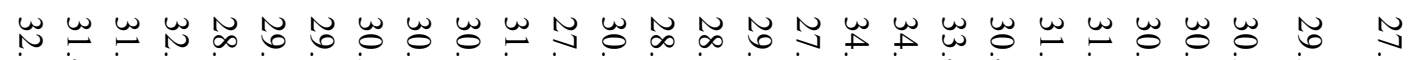

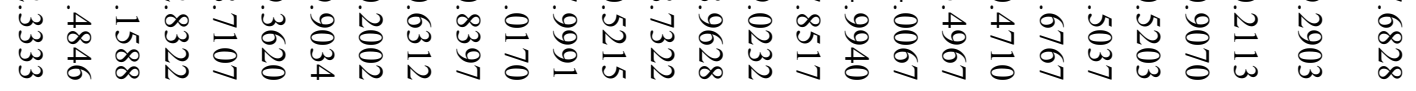

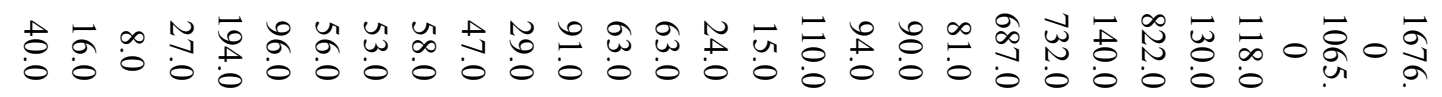

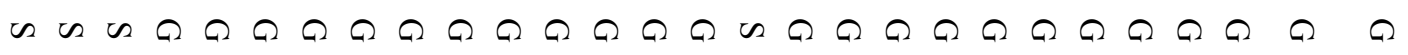

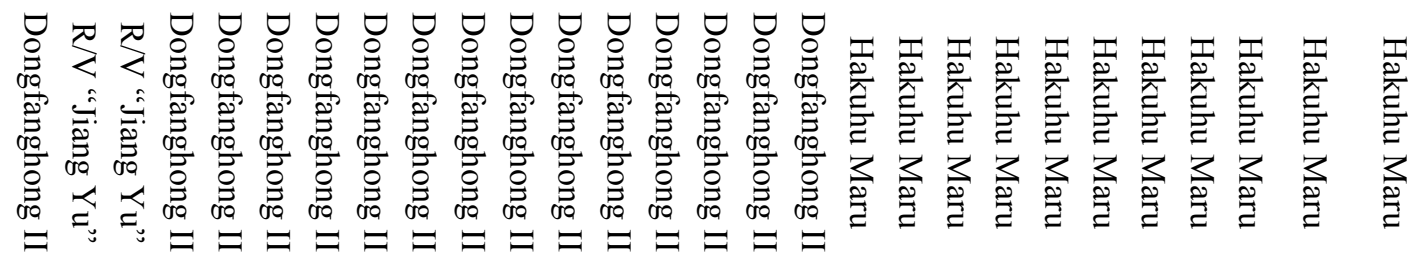

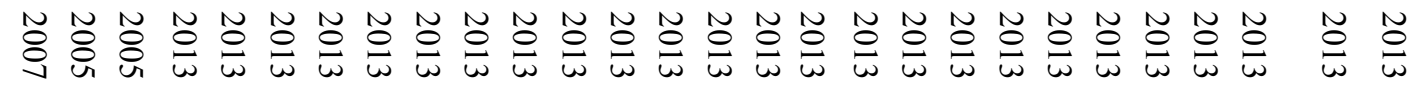

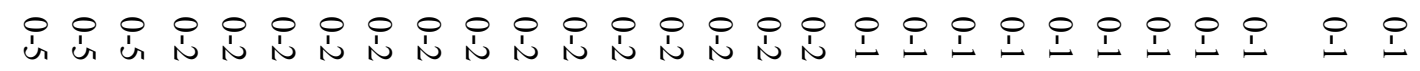

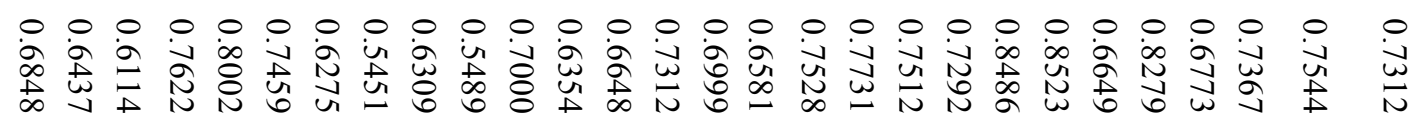

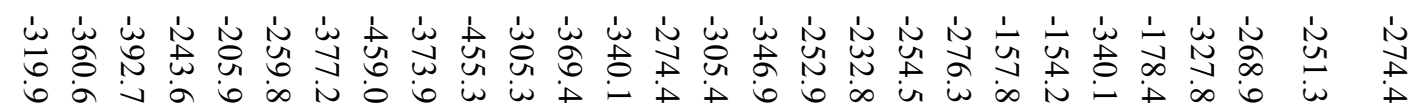

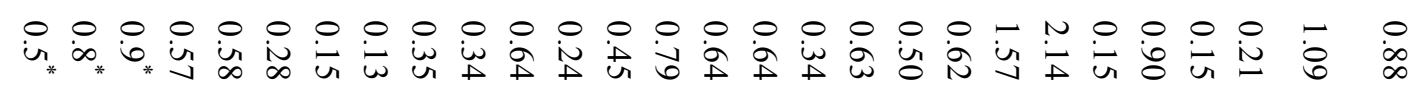

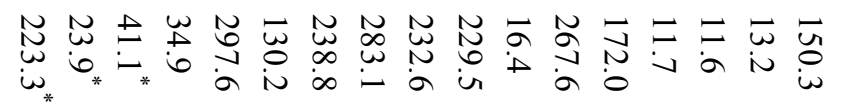

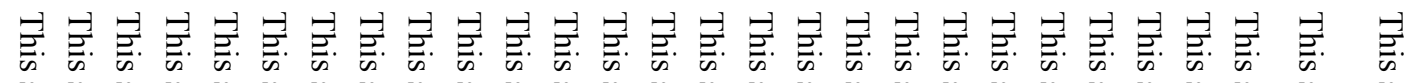

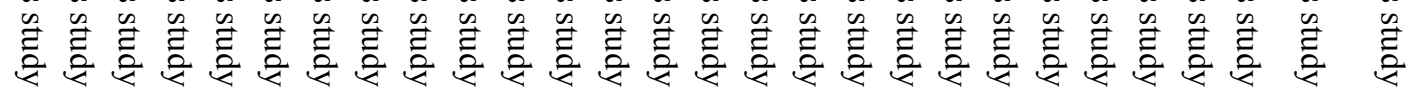




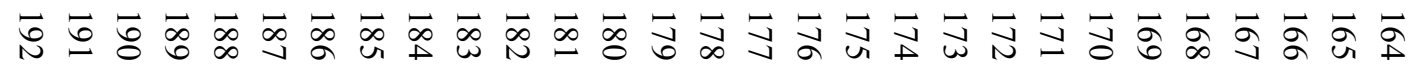

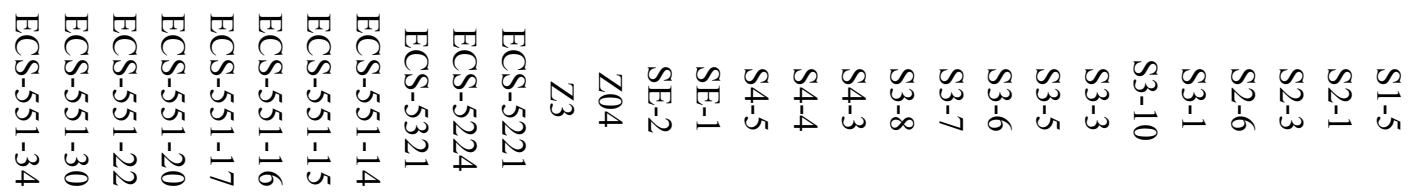

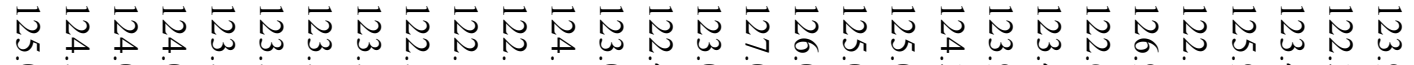

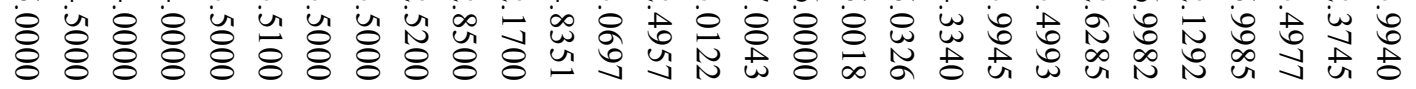

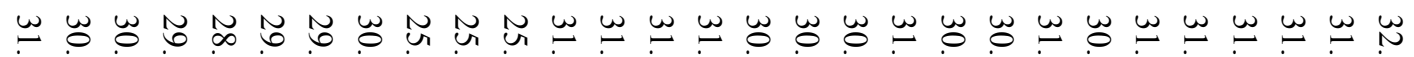

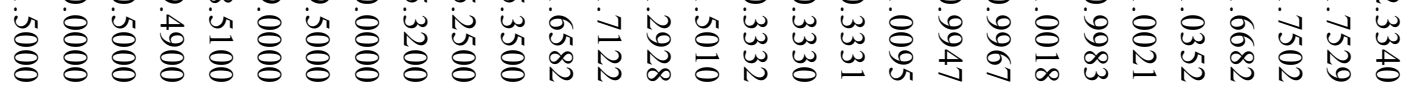

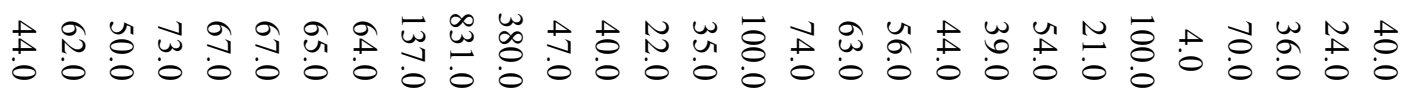

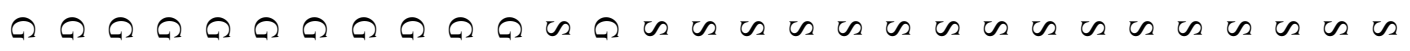

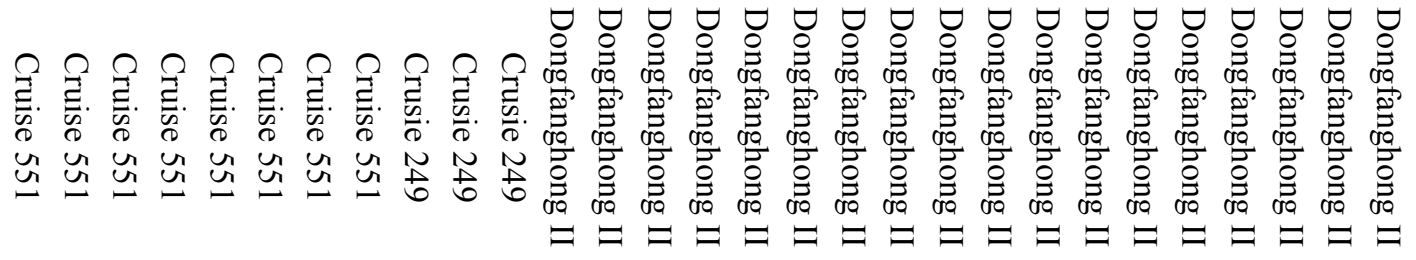

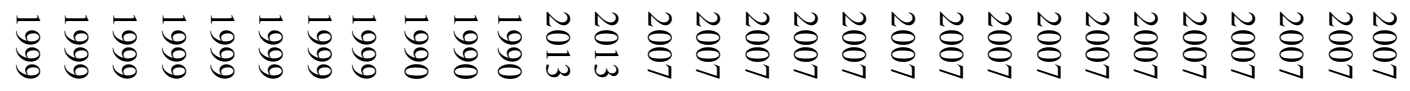

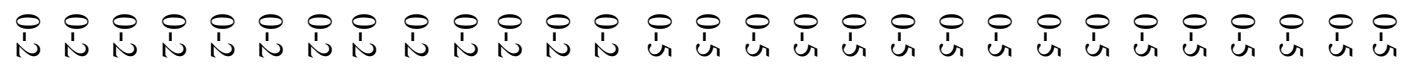

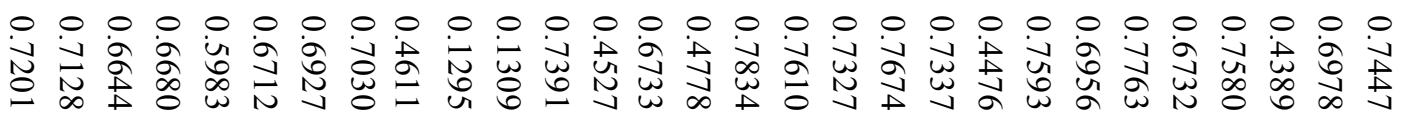

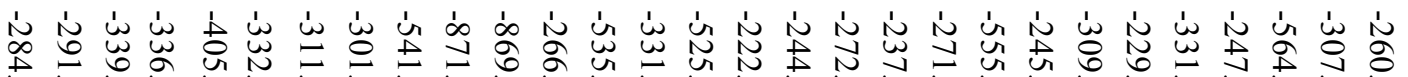
is

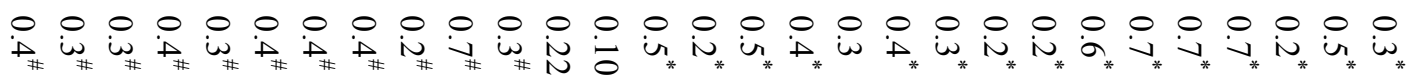

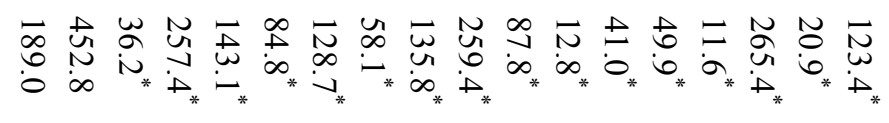

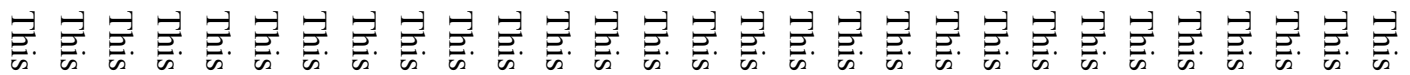

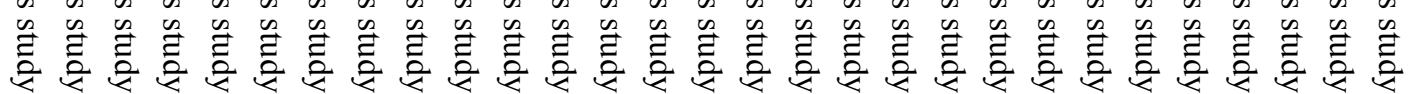




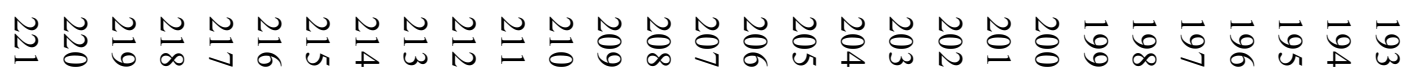

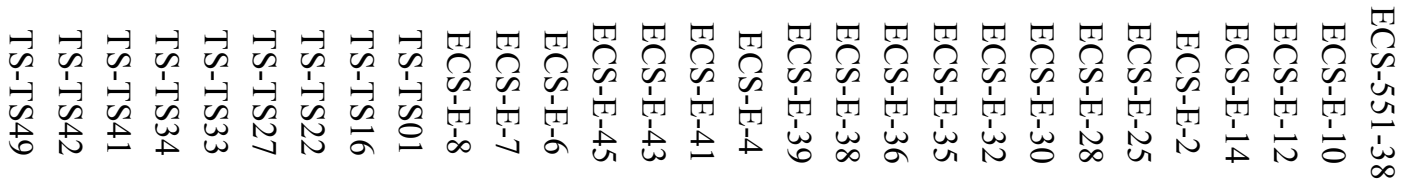

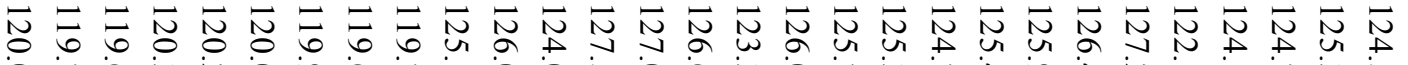

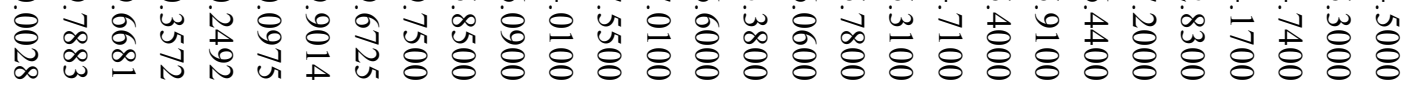

U్ 官

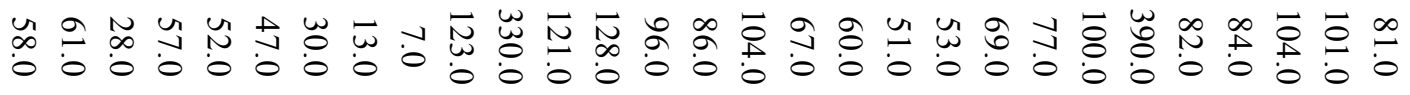

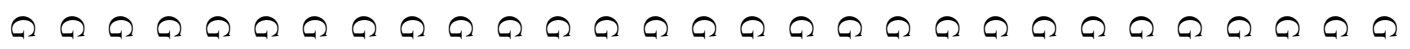

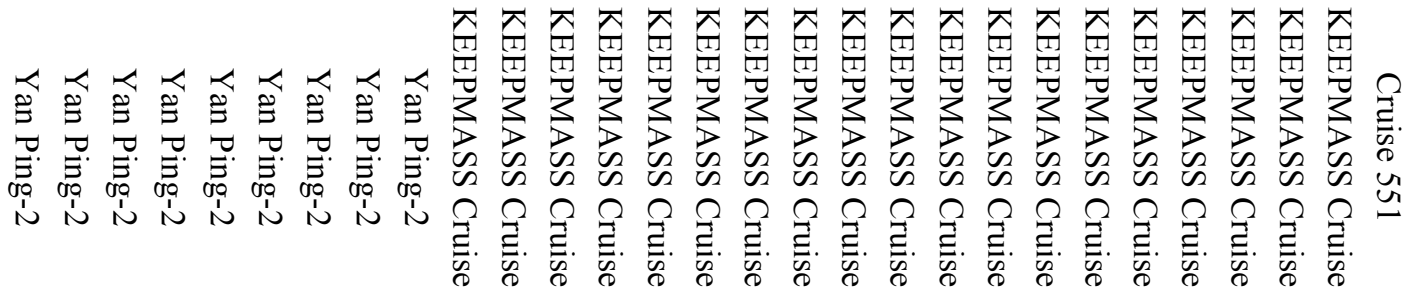

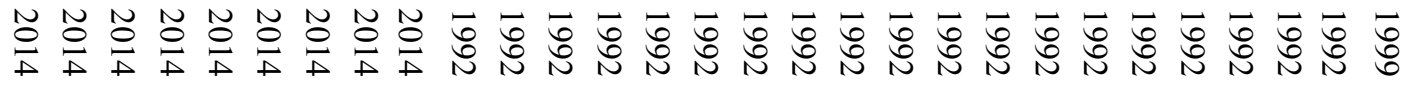

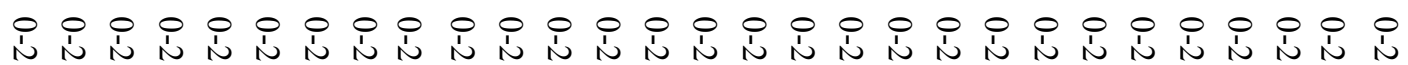

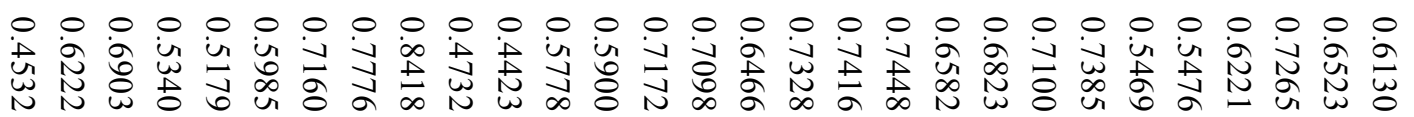

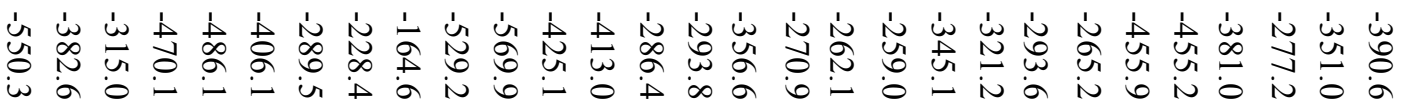

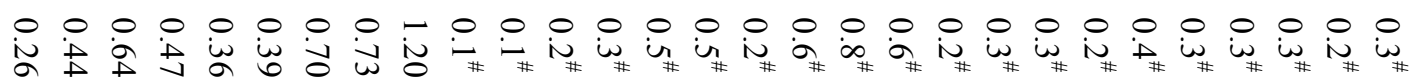

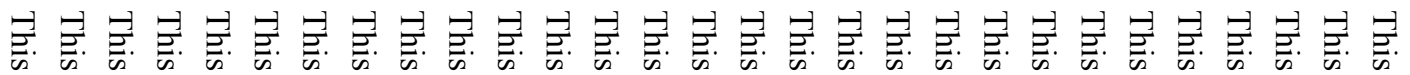

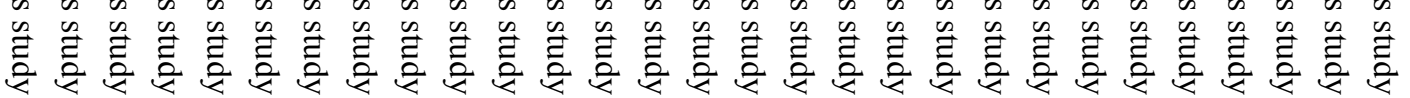




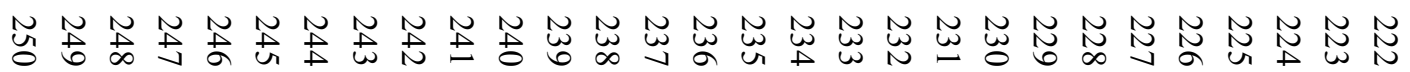

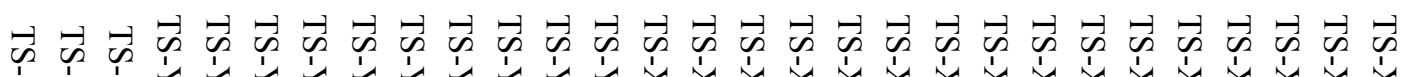

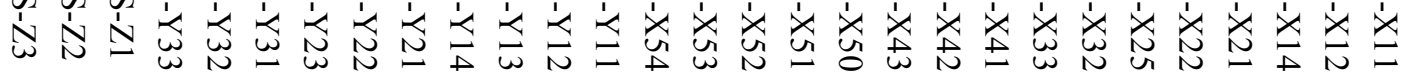

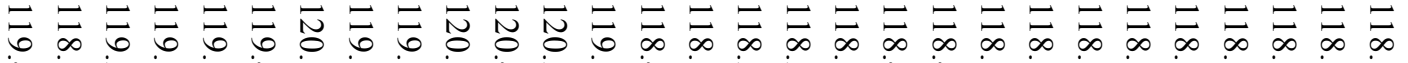

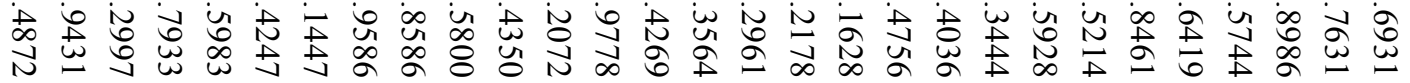

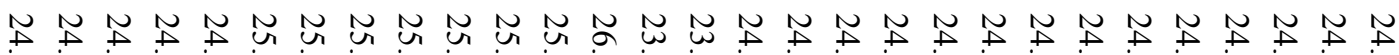

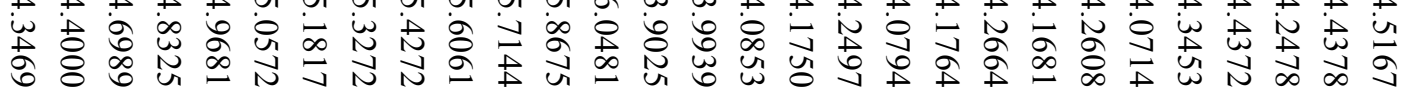
出

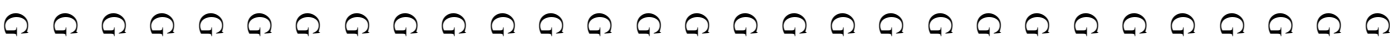

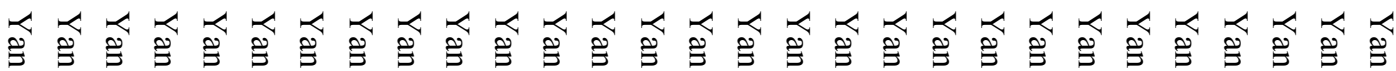

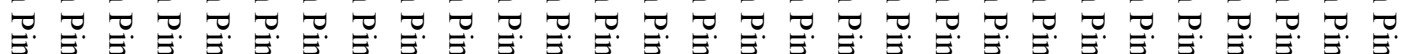

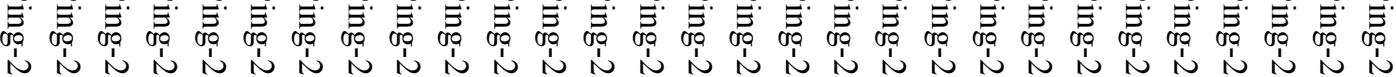

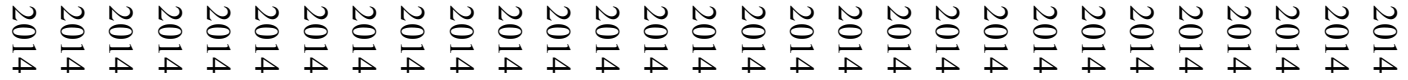

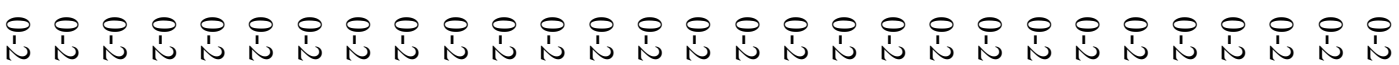

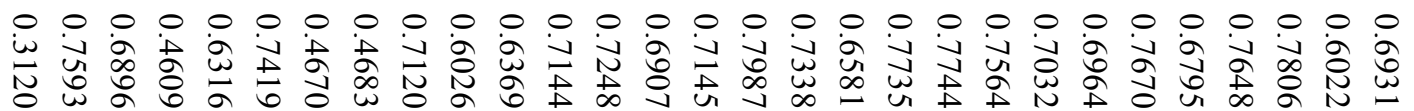
gे 峁

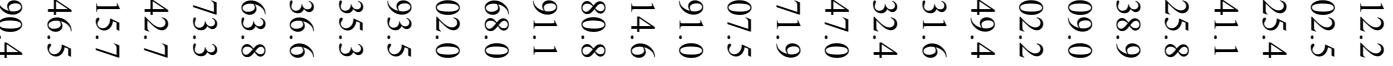

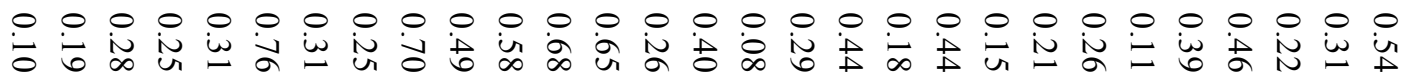

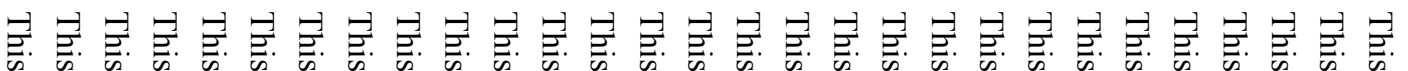

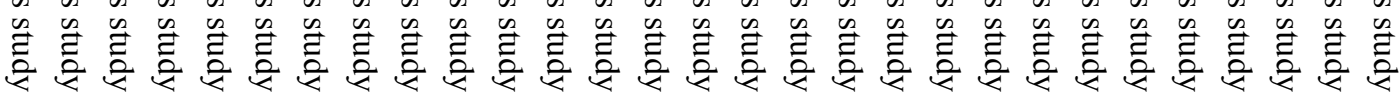




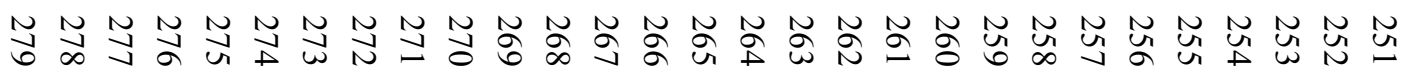

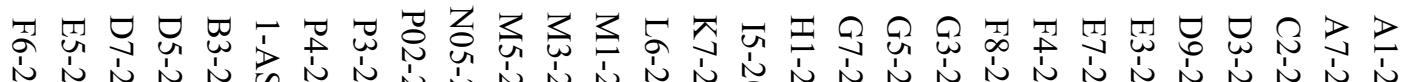

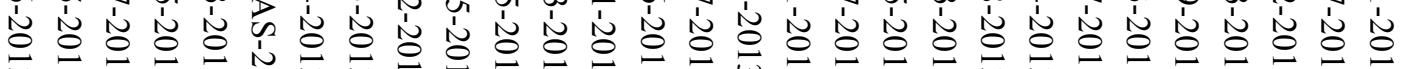

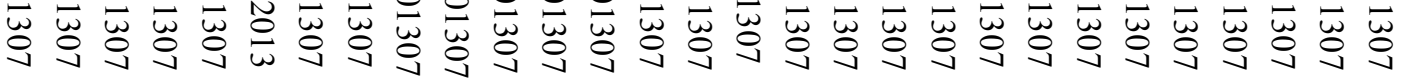

出

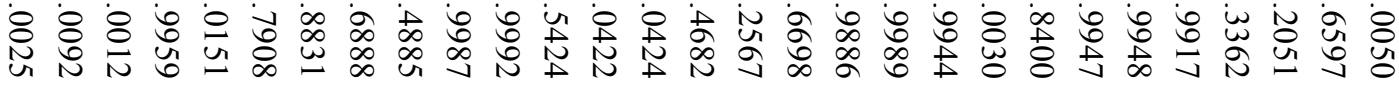

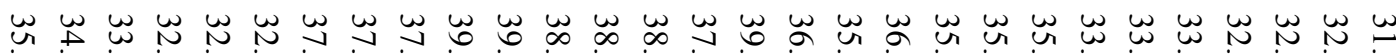

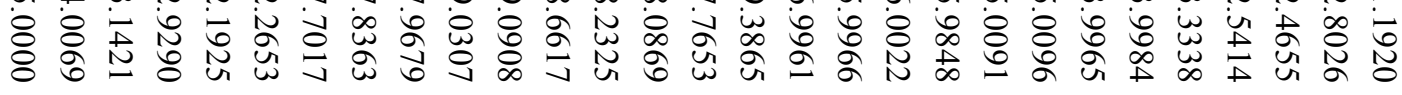

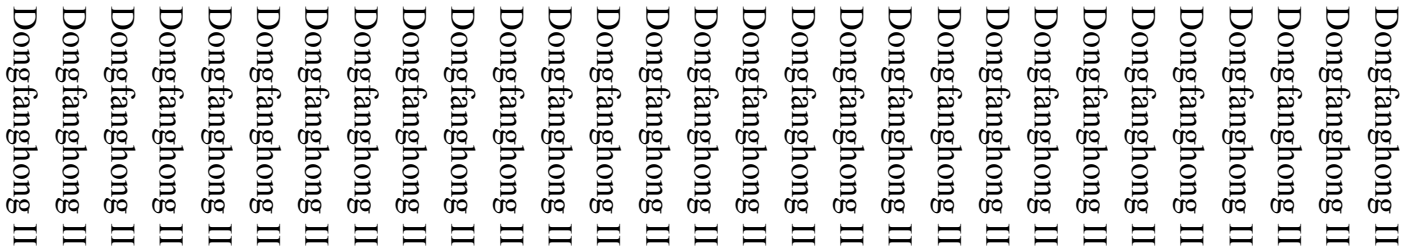

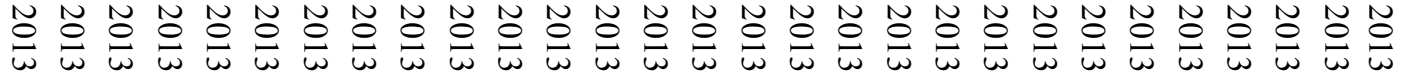

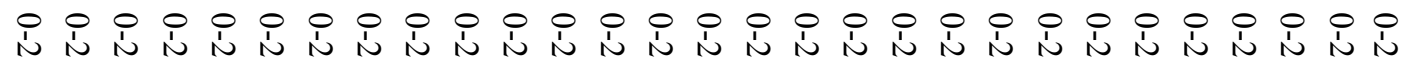

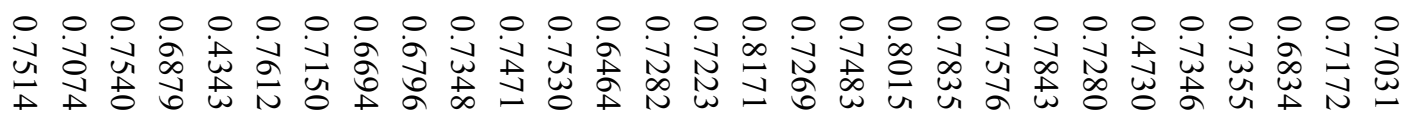

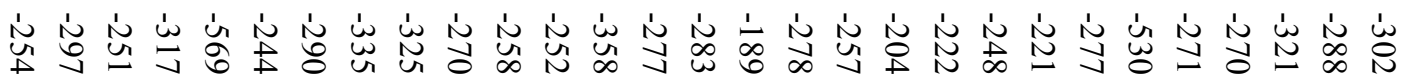

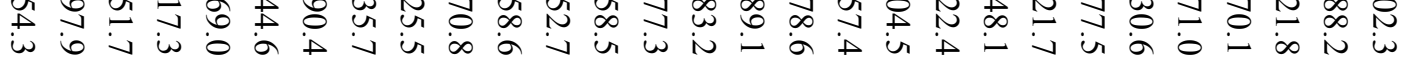

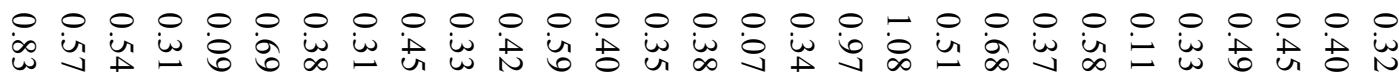

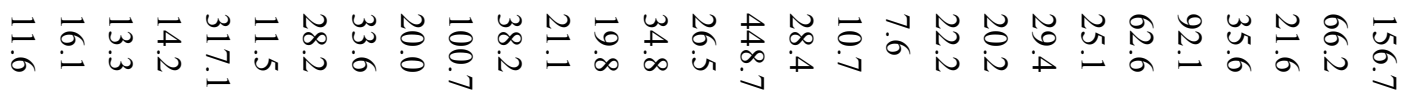

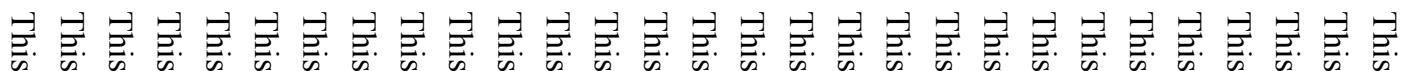

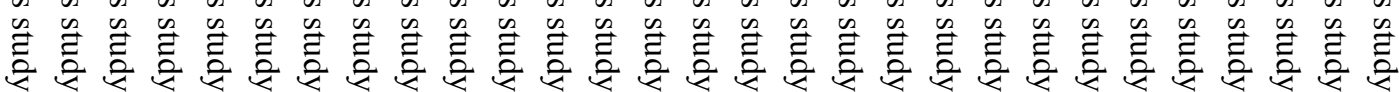




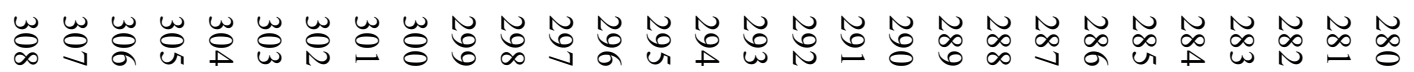

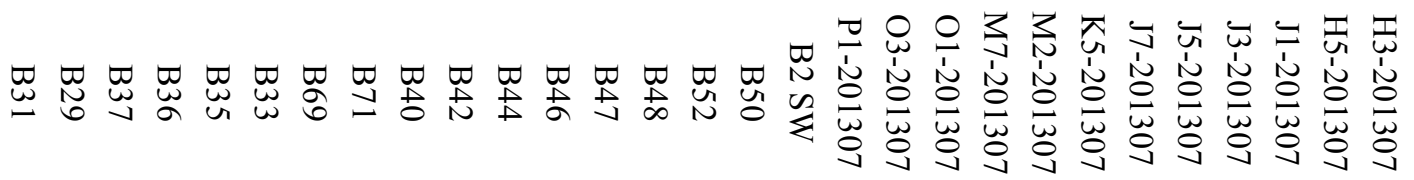

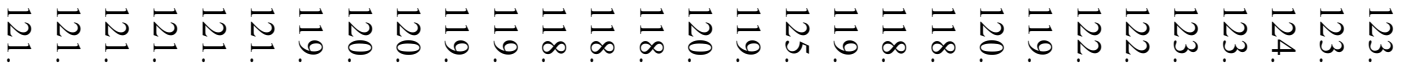

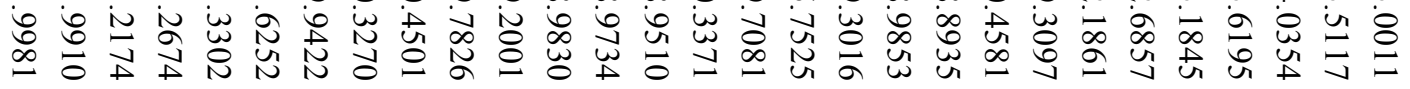

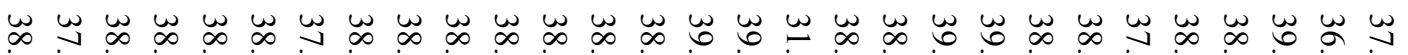

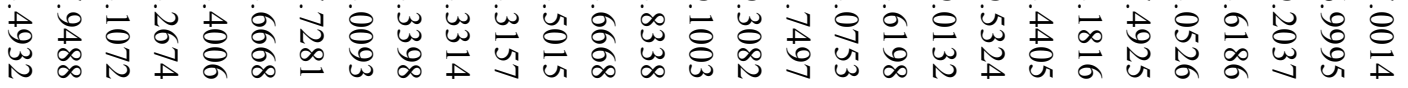
$\mu$

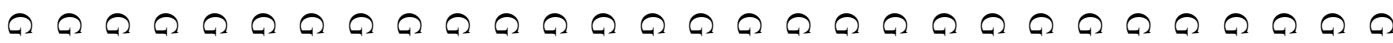

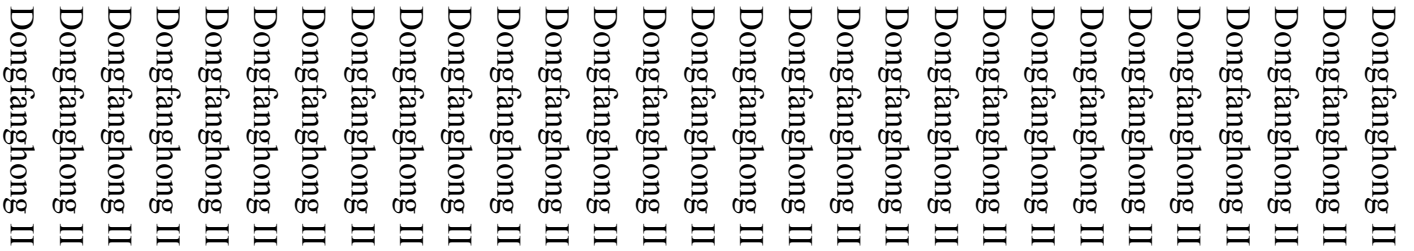

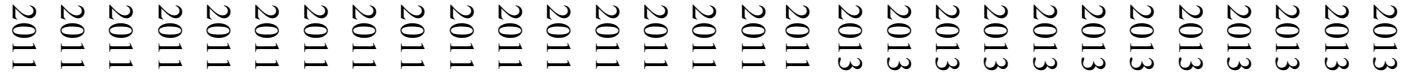

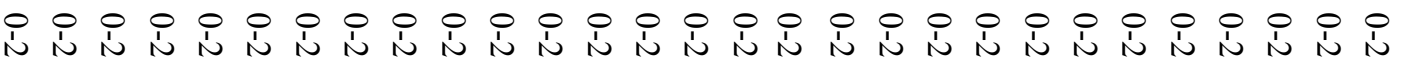

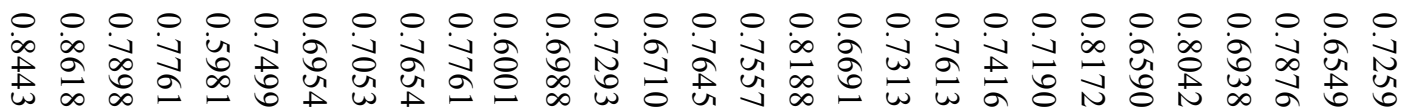

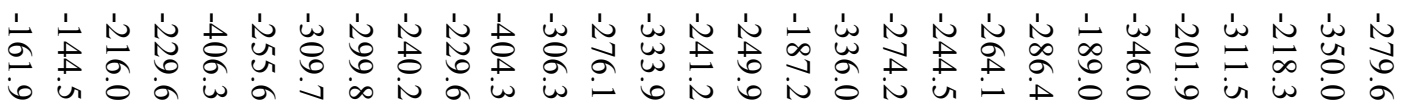

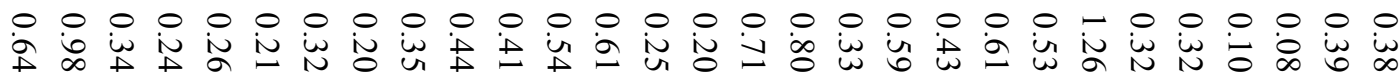

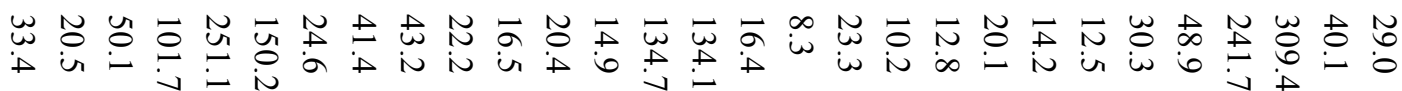

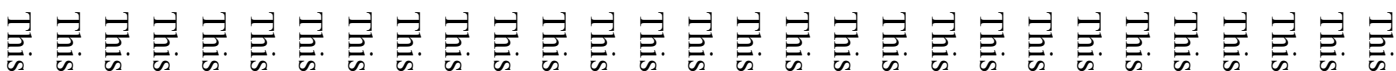

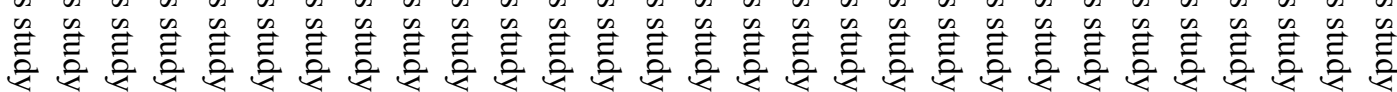




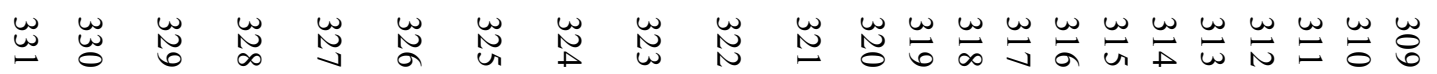

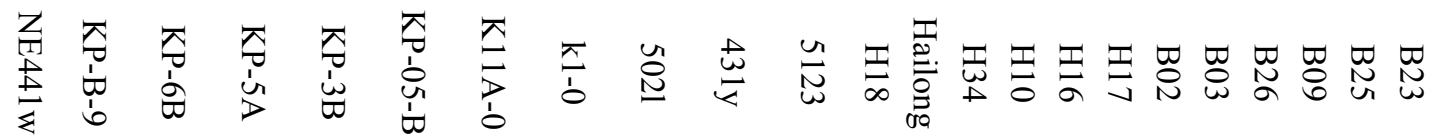

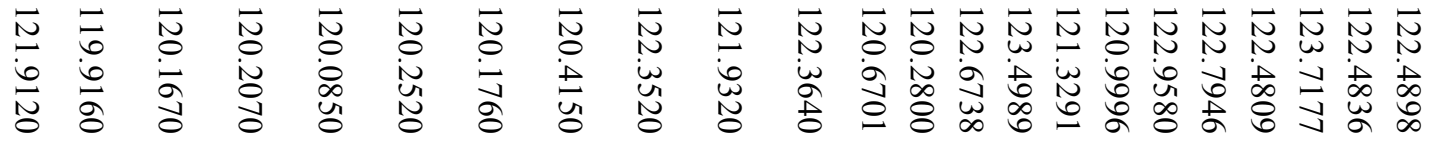

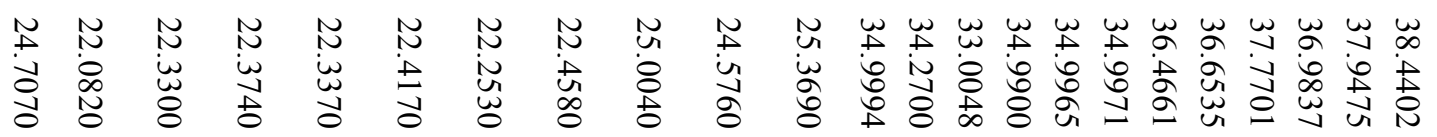
峞 $\Omega \Omega \Omega \Omega \Omega \Omega \Omega \Omega \Omega \Omega \Omega \Omega$

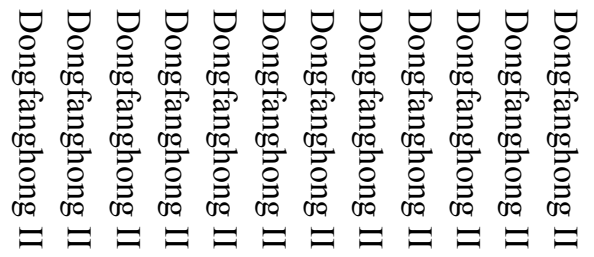

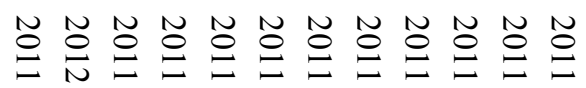

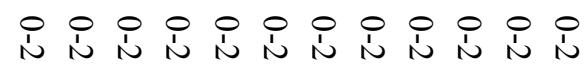

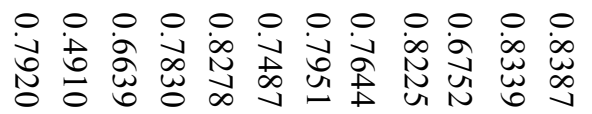

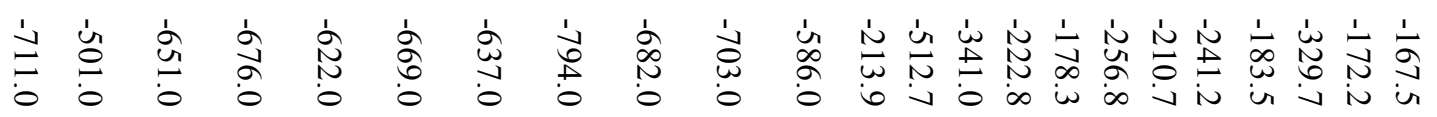

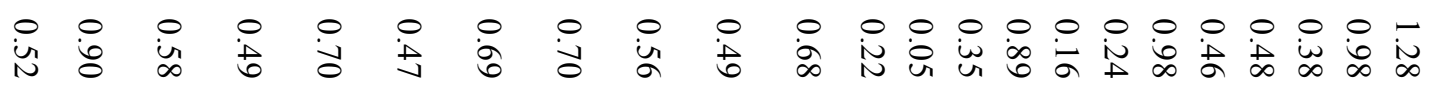

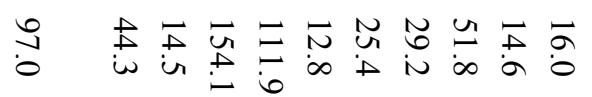

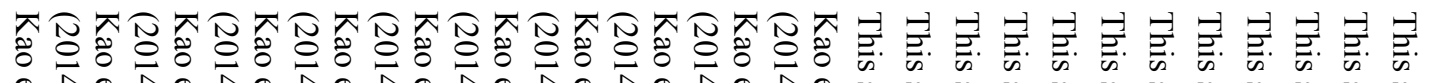

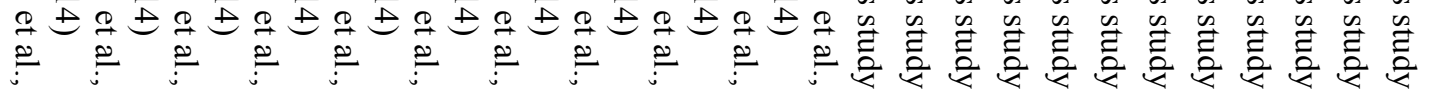




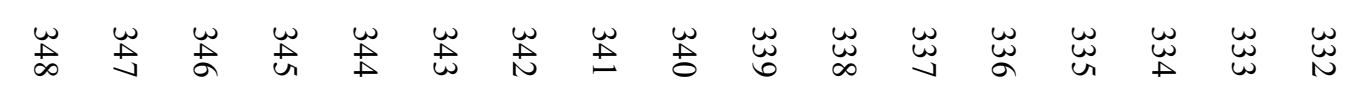

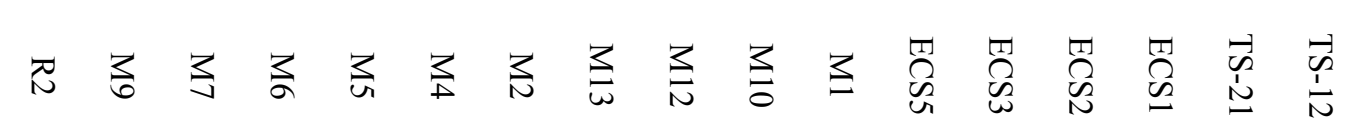

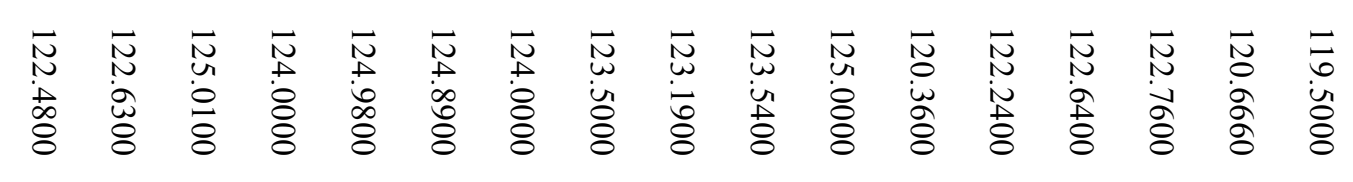

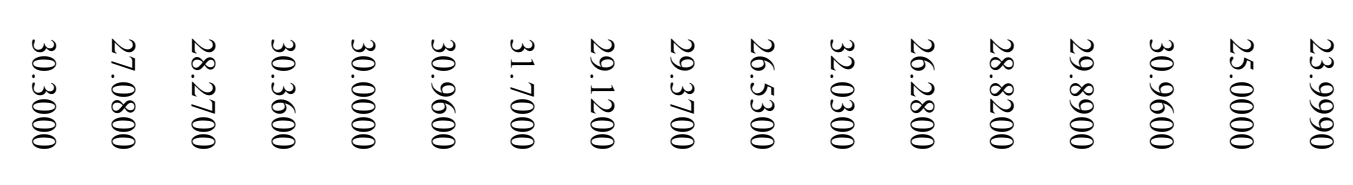

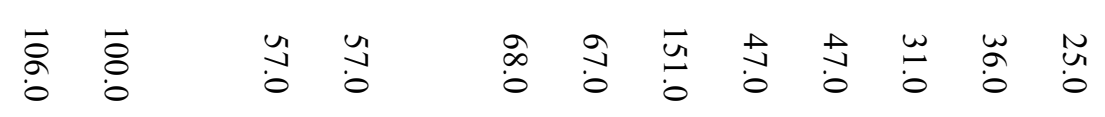

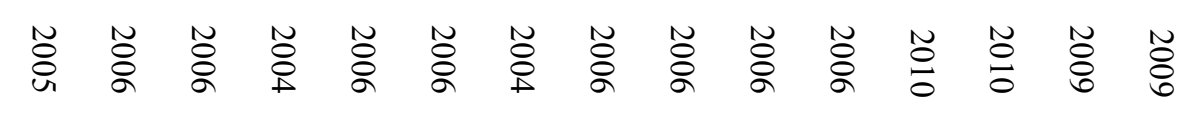

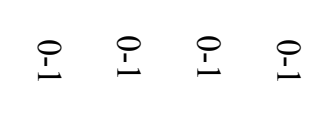

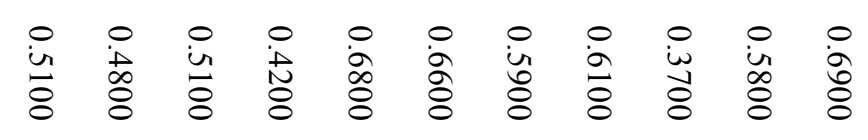

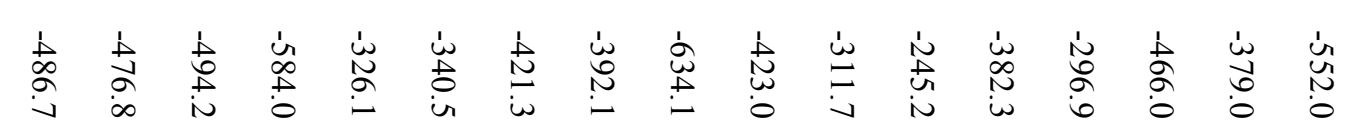

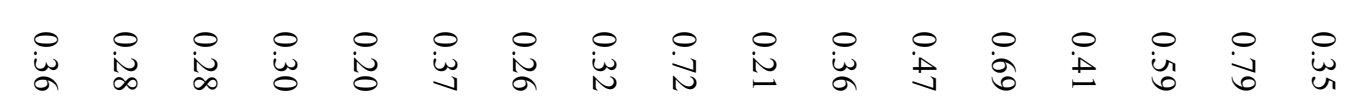

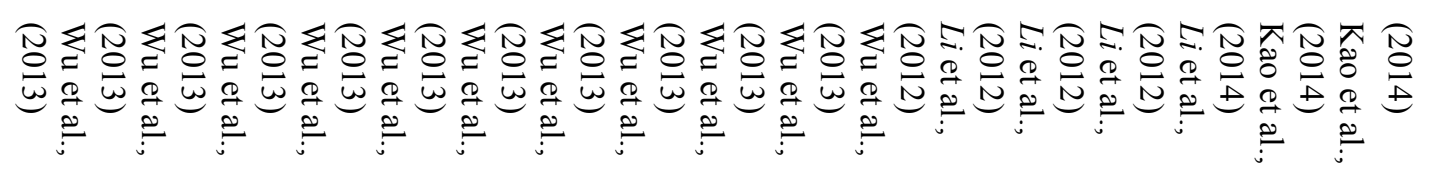




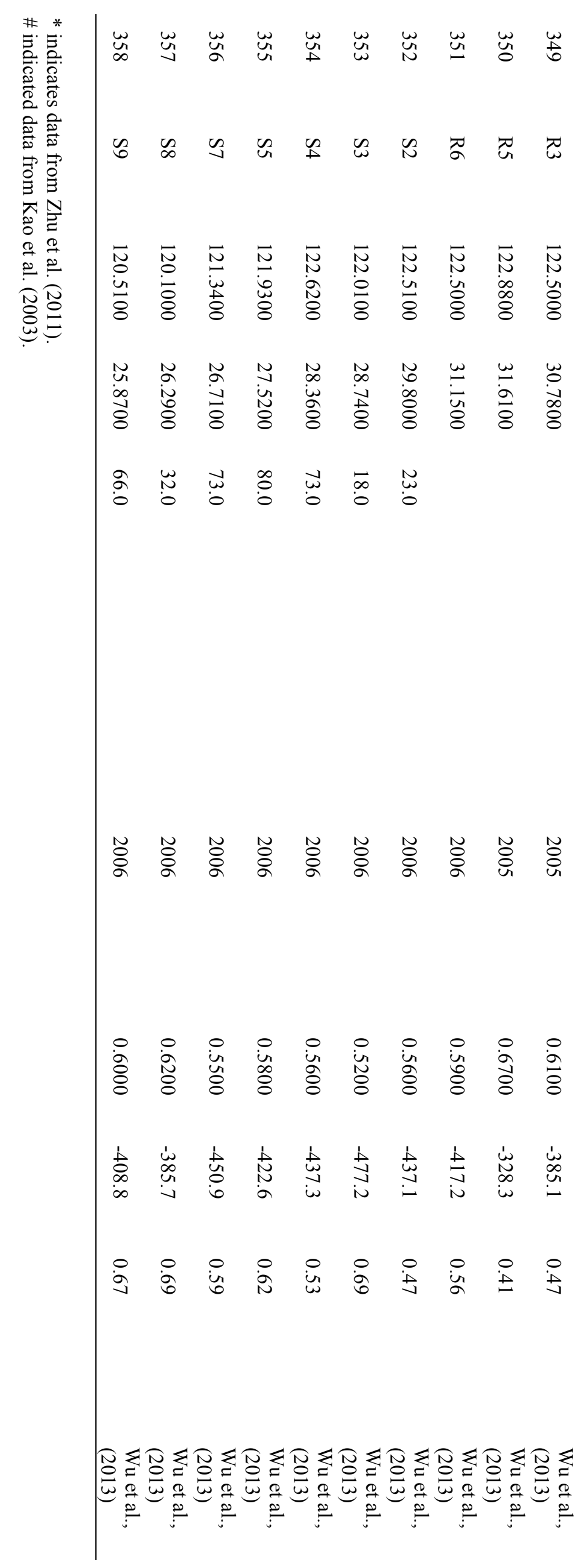




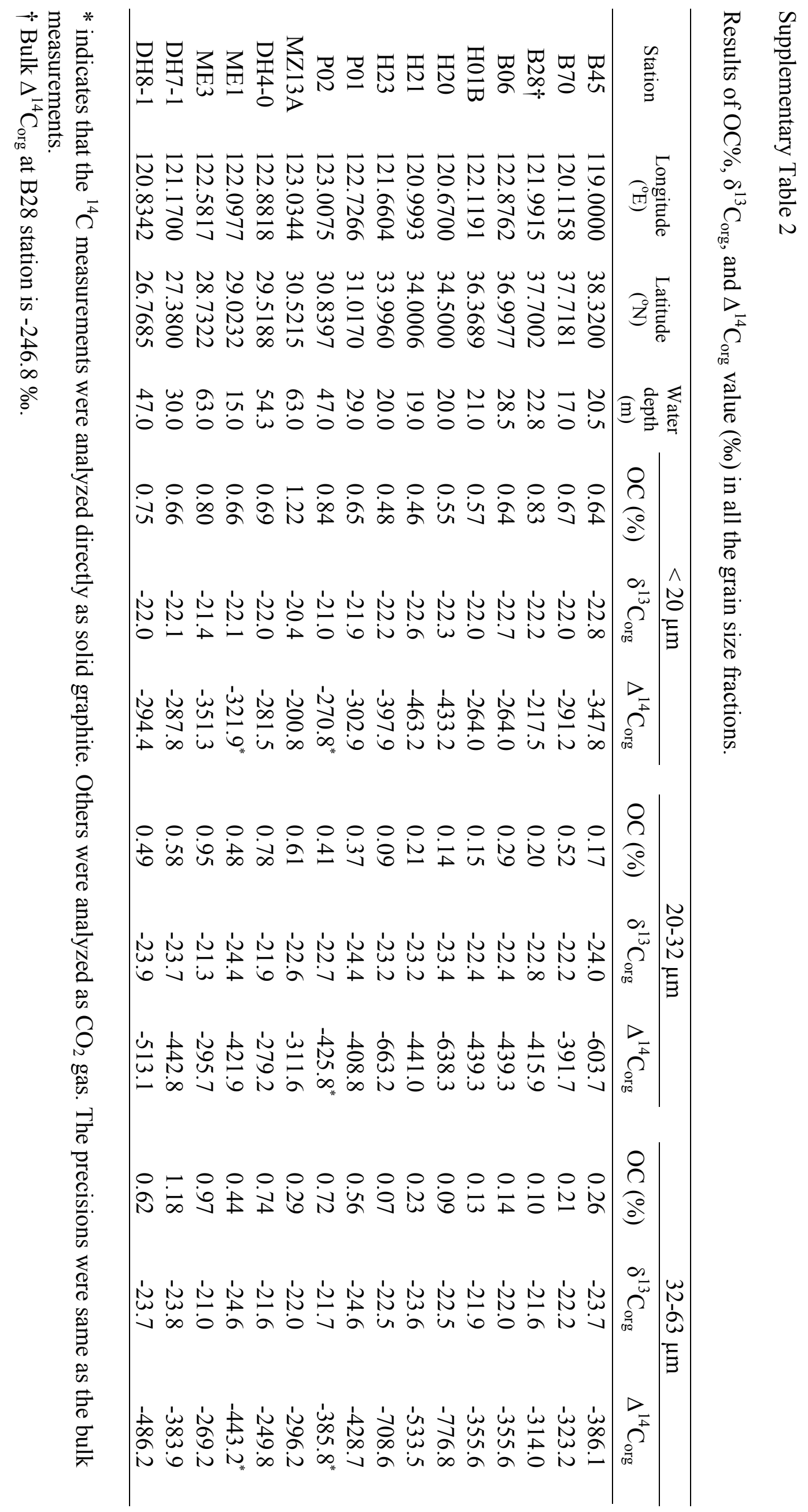




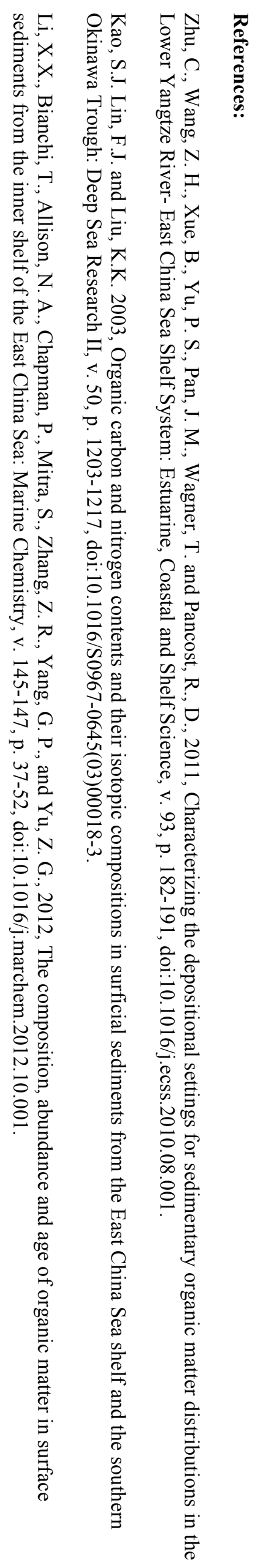

